\section{Smith ScholarWorks}

6-1-2015

\section{Climatic, Ecophysiological, and Phenological Controls on Plant Ecohydrological Strategies in Seasonally Dry Ecosystems}

\author{
Giulia Vico \\ Sveriges lantbruksuniversitet \\ Sally E. Thompson \\ University of California, Berkeley \\ Stefano Manzoni \\ Sveriges lantbruksuniversitet \\ Annalisa Molini \\ Khalifa University of Science and Technology \\ John D. Albertson \\ Duke University
}

See next page for additional authors

Follow this and additional works at: https://scholarworks.smith.edu/egr_facpubs

Part of the Engineering Commons

\section{Recommended Citation \\ Vico, Giulia; Thompson, Sally E.; Manzoni, Stefano; Molini, Annalisa; Albertson, John D.; Almeida-Cortez, Jarcilene S.; Fay, Philip A.; Feng, Xue; Guswa, Andrew J.; Liu, Hu; Wilson, Tiffany G.; and Porporato, Amilcare, "Climatic, Ecophysiological, and Phenological Controls on Plant Ecohydrological Strategies in Seasonally Dry Ecosystems" (2015). Engineering: Faculty Publications, Smith College, Northampton, MA. https://scholarworks.smith.edu/egr_facpubs/30}




\section{Authors}

Giulia Vico, Sally E. Thompson, Stefano Manzoni, Annalisa Molini, John D. Albertson, Jarcilene S. AlmeidaCortez, Philip A. Fay, Xue Feng, Andrew J. Guswa, Hu Liu, Tiffany G. Wilson, and Amilcare Porporato 


\title{
Climatic, ecophysiological, and phenological controls on plant ecohydrological strategies in seasonally dry ecosystems
}

\author{
Giulia Vico, ${ }^{1 *}$ Sally E. Thompson, ${ }^{2}$ Stefano Manzoni, ${ }^{1,3,4}$ Annalisa Molini, ${ }^{5,6}$ John D. Albertson, ${ }^{7,8}$ \\ Jarcilene S. Almeida-Cortez, ${ }^{9}$ Philip A. Fay, ${ }^{10}$ Xue Feng, ${ }^{7}$ Andrew J. Guswa, ${ }^{11} \mathrm{Hu}$ Liu, ${ }^{12,13}$ \\ Tiffany G. Wilson ${ }^{7}$ and Amilcare Porporato ${ }^{7,8}$ \\ ${ }^{1}$ Department of Crop Production Ecology, Swedish University of Agricultural Sciences (SLU), Uppsala, Sweden \\ ${ }^{2}$ Department of Civil and Environmental Engineering, University of California, Berkeley, Berkeley, CA, USA \\ ${ }^{3}$ Department of Ecology, Swedish University of Agricultural Sciences (SLU), Uppsala, Sweden \\ ${ }^{4}$ Department of Physical Geography and Quaternary Geology, Stockholm University, Stockholm, Sweden \\ ${ }_{5}$ iWater Center, Masdar Institute of Science and Technology, Abu Dhabi, United Arab Emirates \\ ${ }^{6}$ Department of Chemical and Environmental Engineering, Masdar Institute of Science and Technology, Abu Dhabi, United Arab Emirates \\ ${ }^{7}$ Department of Civil and Environmental Engineering, Duke University, Durham, NC, USA \\ ${ }^{8}$ Nicholas School of the Environment, Duke University, Durham, NC, USA \\ ${ }^{9}$ Departamento de Botânica, Universidade Federal de Pernambuco, Recife, Brazil \\ ${ }^{10}$ USDA-ARS Grassland Soil and Water Research Laboratory, Temple, TX, USA \\ ${ }^{11}$ Center for the Environment, Ecological Design and Sustainability and Picker Engineering Program, Smith College, Northampton, MA, USA \\ ${ }^{12}$ Linze Inland River Basin Research Station, Chinese Ecosystem Research Network, and Key Laboratory of Ecohydrology and River Basin Science, \\ Chinese Academy of Sciences, Lanzhou, China \\ ${ }^{13}$ Pennsylvania State University, University Park, PA, USA
}

\begin{abstract}
Large areas in the tropics and at mid-latitudes experience pronounced seasonality and inter-annual variability in rainfall and hence water availability. Despite the importance of these seasonally dry ecosystems (SDEs) for the global carbon cycling and in providing ecosystem services, a unifying ecohydrological framework to interpret the effects of climatic variability on SDEs is still lacking. A synthesis of existing data about plant functional adaptations in SDEs, covering some 400 species, shows that leaf phenological variations, rather than physiological traits, provide the dominant control on plant-water-carbon interactions. Motivated by this result, the combined implications of leaf phenology and climatic variability on plant water use strategies are here explored with a minimalist model of the coupled soil water and plant carbon balances. The analyses are extended to five locations with different hydroclimatic forcing, spanning seasonally dry tropical climates (without temperature seasonality) and Mediterranean climates (exhibiting out of phase seasonal patterns of rainfall and temperature). The most beneficial leaf phenology in terms of carbon uptake depends on the climatic regime: evergreen species are favoured by short dry seasons or access to persistent water stores, whereas high inter-annual variability of rainy season duration favours the coexistence of multiple drought-deciduous phenological strategies. We conclude that drought-deciduousness may provide a competitive advantage in face of predicted declines in rainfall totals, while reduced seasonality and access to deep water stores may favour evergreen species. This article has been contributed to by US Government employees and their work is in the public domain in the USA.
\end{abstract}

KEY WORDS seasonally dry ecosystem; Mediterranean climate; savanna; tropical dry forest; water stress; rainfall variability; soil moisture; carbon balance

Received 31 January 2014; Revised 27 June 2014; Accepted 29 June 2014

\section{INTRODUCTION}

Vast areas in the tropics and mid-latitudes experience seasonally dry climates (Figure 1 top). These climates are characterized by a marked seasonality in rainfall occurrence, with one or two wet seasons, during which most of the annual precipitation occurs, followed by extended dry

*Correspondence to: Giulia Vico, Department of Crop Production Ecology, Swedish University of Agricultural Sciences, PO Box 7043, Uppsala, SE-750 07, Sweden. E-mail: giulia.vico@slu.se periods. Rainfall in these seasonally dry ecosystems (SDEs) is typified by large inter-annual variation in precipitation timing and amount (Rao et al., 1993; Joffre et al., 1999; Fatichi et al., 2012; Feng et al., 2013), which is likely to be exacerbated by climate change (Solomon et al., 2007; Garcia-Ruiz et al., 2011; Dominguez et al., 2012). Despite these commonalities, seasonally dry climates - including Mediterranean climates, tropical monsoon climates, and tropical savannas with dry summers or winters - have rarely been considered as a group. This may be because the meteorological drivers of these 

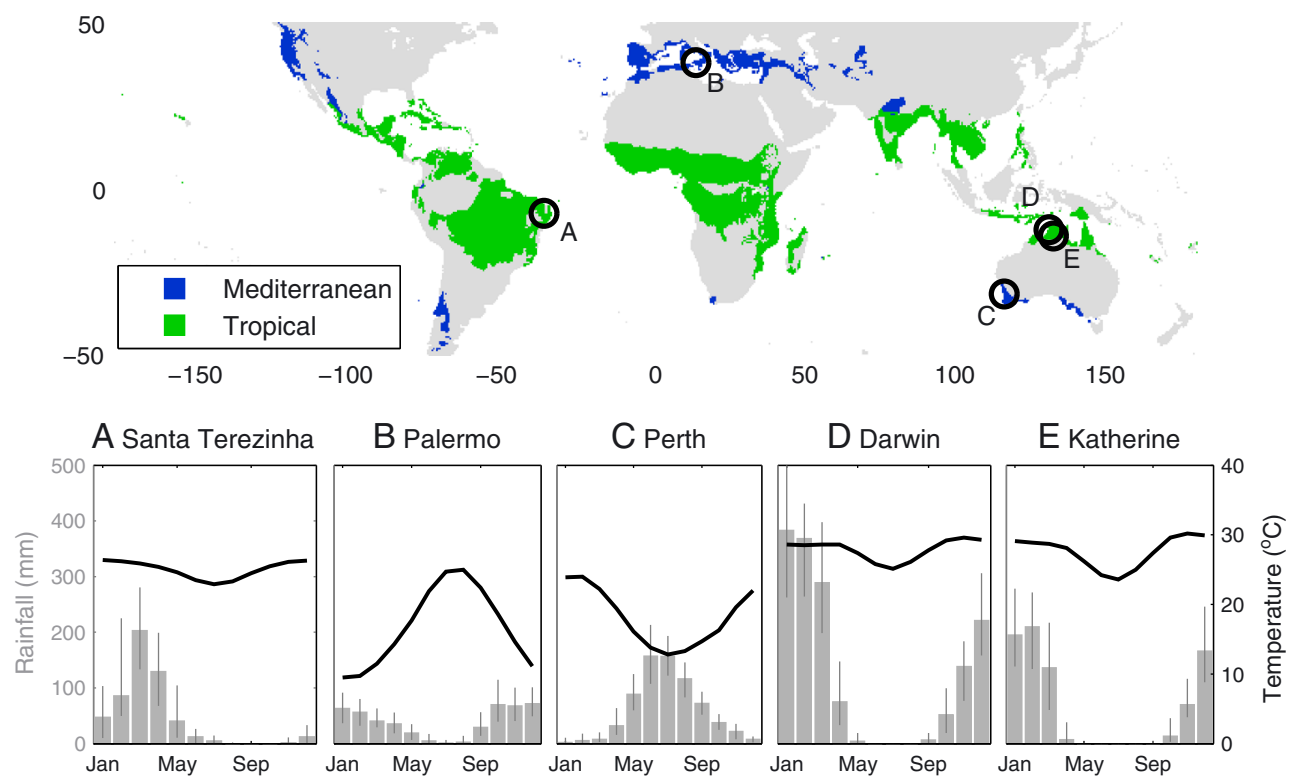

Figure 1. Top: Global distribution of seasonally dry climates: Mediterranean ecosystems correspond to warm temperate climates with dry summer (Cs in Köppen-Geiger classification; see Kottek et al., 2006); tropical seasonally dry ecosystems include Equatorial monsoon and Equatorial savannas with dry summer or winter ( $A m, A w$, and $A s$ in the Köppen-Geiger classification). Bottom: seasonal patterns of median monthly rainfall (bars; whiskers indicate 25 and 75 percentiles) and mean monthly air temperature (lines) in the five selected sites (identified with symbols on the map; main features summarized in Table I). Data sources: monthly rainfall data from Osservatorio Astronomico di Palermo Giuseppe S. Vaiana, Australian Government Bureau of Meteorology, and SUDENE; monthly average temperature data after Legates and Willmott (1989).

climates differ or because of differences in the timing of the wet season - variable in tropical regions, but always occuring during the winter in Mediterranean climates (Figure 1, bottom). The implications of large swings between periods of high water availability and extreme water deficit, however, suggest that seasonally dry climates should be treated as a group for ecohydrological studies.

In tropical SDEs, the natural vegetation ranges from closed-canopy forests (e.g. caatinga, cerrado and chaco in South and Central America, and bushland thickets in Africa), to open forests (e.g. campo cerrado and campo sujo in South America; forêt claire and miombo in Africa), to savannas (e.g. campo limpo in South America; Menaut et al. (1995); Sampaio (1995); Blasco et al. (2000); Lock (2006)). Mediterranean vegetation is often characterized by shrubland (e.g. maquis in Europe, chaparral and oak savannas in California, matorral in Chile), while open eucalyptus woodland is common in Australia (Cody and Mooney, 1978). These varied ecosystem types support crucial biodiversity hotspots (Miles et al., 2006; Klausmeyer and Shaw, 2009) and help sustain local populations by providing food, fibre, and other essential ecosystem services. Nevertheless, the highly variable rainfall in SDEs impacts the reliability of these services (Ellis and Galvin, 1994; Maass et al., 2005). At the same time, SDEs are subject to multiple anthropogenic threats, including soil erosion, deforestation, and increased exploitation of water resources for agricultural and urban use (Miles et al., 2006; Underwood et al., 2009).
Most SDEs experience periods of high water availability during the wet season, eliciting bursts of ecosystem productivity. The subsequent transition to a dry period of unpredictable length, almost always coupled with high temperatures and high vapour pressure deficits (VPD), creates the potential for significant stress and physiological damage to vegetation. These stresses include reduced photosynthesis due to low leaf water potential, stomatal closure, and metabolic limitations (Xu and Baldocchi, 2003; Galmes et al., 2007; Vico and Porporato, 2008; Lawlor and Tezara, 2009; Peguero-Pina et al., 2009); impairment of water transport in xylem due to cavitation (e.g. Tyree and Ewers, 1991); increased respiratory demand due to higher tissue temperatures (Farquhar and Sharkey, 1982); increased susceptibility to herbivores and diseases (McDowell et al., 2011), and risk of tissue damage and mortality (Adams et al., 2009; Allen et al., 2010).

The pronounced seasonal and inter-annual climatic variation in SDEs has produced a bewildering diversity of physiological and phenological strategies in vegetation to cope with the dramatic changes in water availability (Murphy and Lugo, 1986; Bowman and Prior, 2005; Lock, 2006; Lehmann et al., 2009). Plants either try to (i) avoid these stresses by limiting plant physiological activity during dry periods (for example, drought-deciduous species shed their leaves); or (ii) to endure droughts without experiencing stress by developing physiological adaptations that maximize water storage and photosynthetic activity, minimize water loss, and maintain sufficient carbon (C) stores to allow plant survival 
during the dry season (e.g. evergreen species; see Eamus and Prior, 2001). Among drought-deciduous species, two strategies determine the timing at which new leaves are grown (leaf flushing). In 'opportunistic species', leaf flushing occurs as water becomes available, while in 'scheduled species', leaf flushing occurs in response to photoperiod or temperature. Within each of these strategies, plant behaviour can be further categorized as conservative or aggressive based on the time of flushing with respect to rainfall. Conservative plants avoid water stress by flushing leaves late in the wet season (or by dropping them early), which may however result in lost opportunities for $\mathrm{C}$ fixation and growth. By flushing leaves before the wet season or after episodic rain events, aggressive plants may keep leaves longer, but may risk undergoing water stress if drought follows the leaf flush. In comparison to deciduous species, drought endurers such as evergreen species may transpire for longer periods of time but must rely on water and $\mathrm{C}$ stored from the wet season; in some cases, these supplies may be insufficient to sustain plant water use and respiration over the dry season (Gartner et al., 1990). Therefore, given the unpredictability of rainfall, each strategy poses its own set of risks to plants (Hoffman and Walker, 1980; Machado et al., 1997; Jolly and Running, 2004; Singh and Kushwaha, 2005a; Hasselquist et al., 2010; ValdezHernandez et al., 2010; Markesteijn et al., 2011; Pringle et al., 2011). The presence of inherent risks and ecophysiological tradeoffs in each of these strategies makes the outcome of species competition and selection difficult to predict. This lack of clear advantages of one strategy over the others likely favours coexistence and nuanced variations in the predominant ecohydrological behaviour across climates.

The aim of this study is to provide insight into the relationship between rainfall regimes (including its interannual variability) and the most effective plant strategies, with a focus on perennial woody vegetation. We expect the leaf phenology and the functional traits associated with water availability to be the primary driver of plant adaptive strategies in SDEs. While a complete understanding of the species and strategy diversity of SDEs requires consideration of evolutionary constraints, ecological dynamics, disturbance, and succession regimes, here we focus on annual net $\mathrm{C}$ gain as a proxy of plant fitness. On this basis, a theoretical framework is proposed for analysis of the $\mathrm{C}$ and water balances at the plant level to assess the benefits of adaptation strategies in a variety of SDEs.

To provide realistic climatic scenarios for the theoretical analyses, we selected long climatic time series from five locations to represent the diversity of SDEs, in terms of both climate and the most common plant strategy (Table I, Figure 1). In Section on Precipitation Forcing, the rainfall patterns and their variability in three of these locations are analysed. Section on Vegetation Adaptation Strategies reviews physiological and phenological traits of woody vegetation in SDEs. The findings of this synthesis are used

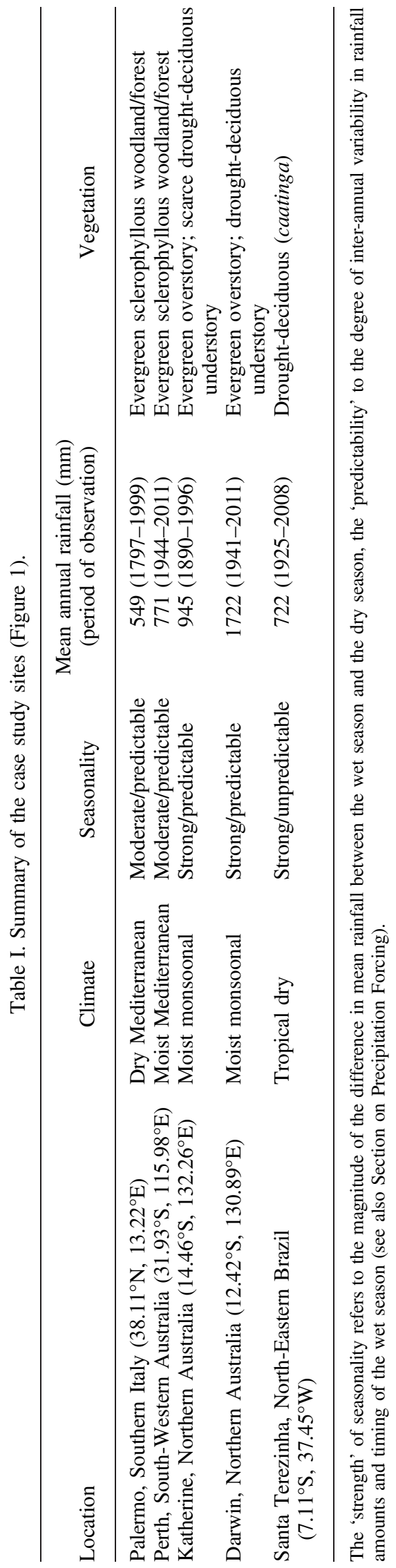

Ecohydrol. (2014) 
to guide the parameterization of a minimalist water and $\mathrm{C}$ economy model (Section on Modelling Framework). The results of the analyses are discussed in Section on Quantitative Assessment of Phenological Strategies with reference to observations. Additional disturbances as drivers of phenological strategy are briefly discussed in Sections on NonEcohydrological Drivers of Leaf Phenology.

\section{PRECIPITATION FORCING}

Seasonally dry climates (Figure 1) share a strong seasonality and a high degree of inter-annual variability in rainfall, even though they are outcomes of very different physical drivers of the global climate - for instance, the movement of the inter-tropical convergence zone or the dynamics of the West African, Asian-Australian, and North American monsoons. To illustrate commonalities and differences across seasonally dry climates, we analysed the rainfall regime of three representative locations: Santa Terezinha (tropical dry climate), Katherine (moist, tropical monsoon climate) and Palermo (Mediterranean climate; Table I).

Figure 1 (bottom) illustrates the seasonality and interannual variability in monthly rainfall and temperature, while examples of intra-annual variability in rainfall are reported in Figure 2A-C. Synoptic and planetary patterns modulate rainfall variability across a wider range of temporal scales, spanning from few months to decades. The scale-by-scale contributions can be resolved through the use of signal filtering techniques such as the continuous wavelet transform. This spectral technique decomposes the total variability of a signal (e.g. daily rainfall) in terms of both time and characteristic scale of the fluctuations (Torrence and Compo, 1998; Molini et al., 2010). Figure 2D-F shows the average wavelet spectra for the three locations, thus offering an integrated picture of the time scales of rainfall variability. The seasonal variation in rainfall (i.e. the annual cycle) is the dominant peak in all three spectra and is therefore the most important source of variation. The difference in the power of the annual peaks across locations corresponds to the difference in mean rainfall in the dry season and the wet season and represents the strength of rainfall seasonality: stronger in the tropical moist climate (Katherine; Figure 2D) and weaker in the Mediterranean climate (Palermo; Figure 2F). Katherine and Santa Terezinha (Figure 2D and E) also exhibit a smaller peak in spectral energy at sub-annual time scales - the result of secondary, 'minor', wet and dry seasons, which are common in tropical climates but become less important away from the equator (Murphy and Lugo, 1986). Although none of these peaks are statistically significant (see, e.g. Torrence and Compo, 1998 for details on the significance test adopted here), lower magnitude peaks in the power spectra are suggestive of a degree of coupling with synoptic circulation and slowly oscillating climatic patterns, such as El Niño-Southern Oscillation, the Indian
Ocean Dipole, and the Pacific Decadal Oscillation (Kane, 1997; Mason and Goddard, 2001; Kayano and Andreoli, 2006; Rodrigues et al., 2011).

Wavelet analysis also allows the exploration of nonstationarity by means of scale-time decomposition diagrams (Figure 2G-I). In these plots, the spectral power (ranging from low in green to high in dark red in Figure 2G-I) measures how important the variability on a particular time scale is (vertical axis), at a given moment in time (horizontal axis). For example, the annual signal for the three sites is easily identified as the dark horizontal band, with regions of significant power contoured in white. At Katherine (Figure $2 \mathrm{G}$ ), this signal is continuous in time, appearing with similar intensity every year. At Santa Terezinha (Figure $2 \mathrm{H}$ ), this signal becomes intermittent: the very weak annual signals correspond to major droughts and strong El NiñoSouthern Oscillation events. At Palermo, the annual power decreases from the 1960s onward, as apparent from the almost total absence of white contoured areas after 1960 in Figure 2I): this pattern corresponds to a known drying trend over the Mediterranean region (Knippertz et al., 2003; Brunetti et al., 2004; Kostopoulou and Jones, 2005; Rodrigo and Trigo, 2007; Alpert et al., 2008). Similar drying trends have been noticed in Western Africa, but not in other tropical SDEs (Feng et al., 2013).

In summary, differences in rainfall patterns across SDEs include the strength of the seasonality (with strongest seasonality in the wet tropics); extent of interannual variability in annual rainfall amounts (greatest in the dry tropics); and differences in the degree of interannual variability of the timing of the wet season (greatest in the dry tropics). Despite these differences, all the selected sites share a strong seasonality in rainfall occurrence, with well-defined wet and dry seasons, and often a high degree of inter-annual variability in rainfall timing and amounts. These shared characteristics justify their common identification as seasonally dry climates for the purposes of ecohydrological analyses. In the following, the effects of these rainfall regimes on plant water availability and hence plant activity will be characterized.

\section{VEGETATION ADAPTATION STRATEGIES}

This section reviews and synthetizes the range of phenological strategies and physiological traits observed in a variety of species and SDEs.

\section{Leaf phenological strategies}

Leaf habit varies significantly across woody species in SDEs. The mechanisms that induce leaf flushing or abscission may be complex and the relative roles of endogenous and exogenous 

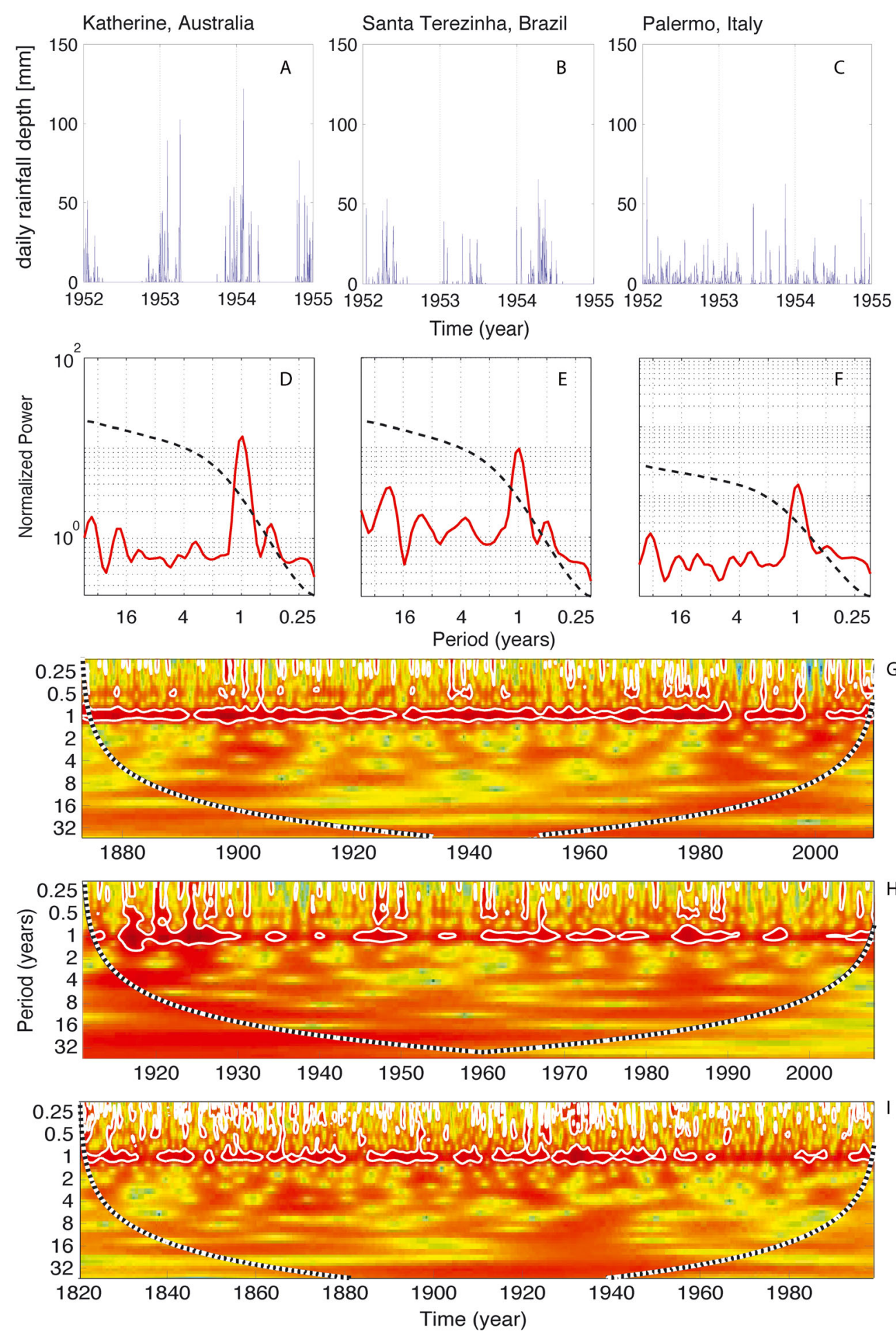

Figure 2. Multi-scale variability of rainfall at (A,D,G) Katherine (Northern Australia, moist tropical SDE), (B,E,H) Santa Terezinha (NE Brazil, dry tropical SDE) and (C,F,I) Palermo (Southern Italy, Mediterranean SDE). In (A-C), examples of 3-year subsamples extracted from daily rainfall time series. Panels (D-F) show the corresponding spectral densities averaged over the complete time series (dashed lines indicate the $95 \%$ significance level for the average power when tested against a Monte Carlo simulated 'red noise' process (Fraedrich and Larnder, 1993; Torrence and Compo, 1998). Panels (G-I) show the scale-time decomposition of rainfall variability via wavelet analysis applied to monthly data (colours indicate the total normalized power, ranging from green for low power to dark red for high power; black and white dashed lines show the cone of influence for the wavelet total power i.e. the $95 \%$ confidence limits for the local spectrum - while white thin contours highlight regions of significant power). 
factors in driving leaf phenology in individual species are not always well known (Borchert and Rivera, 2001; Brodribb et al., 2002; Choat et al., 2006; Ishida et al., 2010). Nevertheless, following the approach of Borchert (1994); Eamus and Prior (2001); Singh and Kushwaha (2005a), and Elliott et al. (2006), we distinguish three main leaf phenological strategies (Table II): (i) opportunistic droughtdeciduous species (Section on Opportunistic DroughtDeciduous Species); (ii) scheduled drought-deciduous species (Section on Scheduled Drought-Deciduous Species); and (iii) evergreen species (Section on Evergreen Species). It should be noted, however, that not all species conform to this classification.

Opportunistic drought-deciduous species. The leaf phenology of opportunistic drought-deciduous species is mainly driven by water availability. Leaf flush occurs following the first significant rainfall event in the wet season, with events of $20-30 \mathrm{~mm}$ or relative volumetric soil water content exceeding $0.13-0.18 \mathrm{~m}^{3}$ water $\mathrm{m}^{-3}$ soil pore space typically needed to induce flushing (Yoshifuji et al., 2011). Flushing is generally synchronous among conspecific trees, although spatial variability in rainfall, infiltration, and soil moisture stores may lead to spatial variations in flushing dates (e.g. Penuelas et al., 2004; Singh and Kushwaha, 2005b). Leaf flush can also be triggered by environmental cues that precede the wet season, such as decreased atmospheric water demand in association with small rainfall events during the dry season (Borchert, 1994; Williams et al., 1997). Opportunistic flushing is typical in tropical species, but it has also been observed in warm Mediterranean ecosystems, where a second flush of leaf growth may be triggered by autumn rainfall (Penuelas et al., 2004).

Among species that display opportunistic flushing, two different patterns of leaf abscission occur. (i) Softwood species tend to shed their leaves early in the dry season. Leaf abscission begins shortly after the rains stop, in response to the first signs of soil water shortage (Reich and Borchert, 1984; Borchert, 1994; Machado et al., 1997; Singh and Kushwaha, 2005a; Fallas-Cedeno et al., 2010; Lima and Rodal, 2010). The plants enter a dormant state but maintain a relatively high stem water potential (Borchert and Rivera, 2001). (ii) Conversely, hardwood species generally shed their leaves later in the dry season, often 2-3 months after the last rain event. Leaf abscission in these trees appears to occur in response to declining leaf or stem water potential. Irrigation or groundwater sources may delay the onset or slow the rate of leaf abscission (Myerscough and Murray, 1992; Valdez-Hernandez et al., 2010). However, plants can lose leaves even when soil moisture remains high, suggesting that the leaf drop may also respond to increased VPD at the end of the wet season (Reich and Borchert, 1984; Wright and Cornejo, 1990; Myerscough and Murray, 1992; Williams et al., 1997).

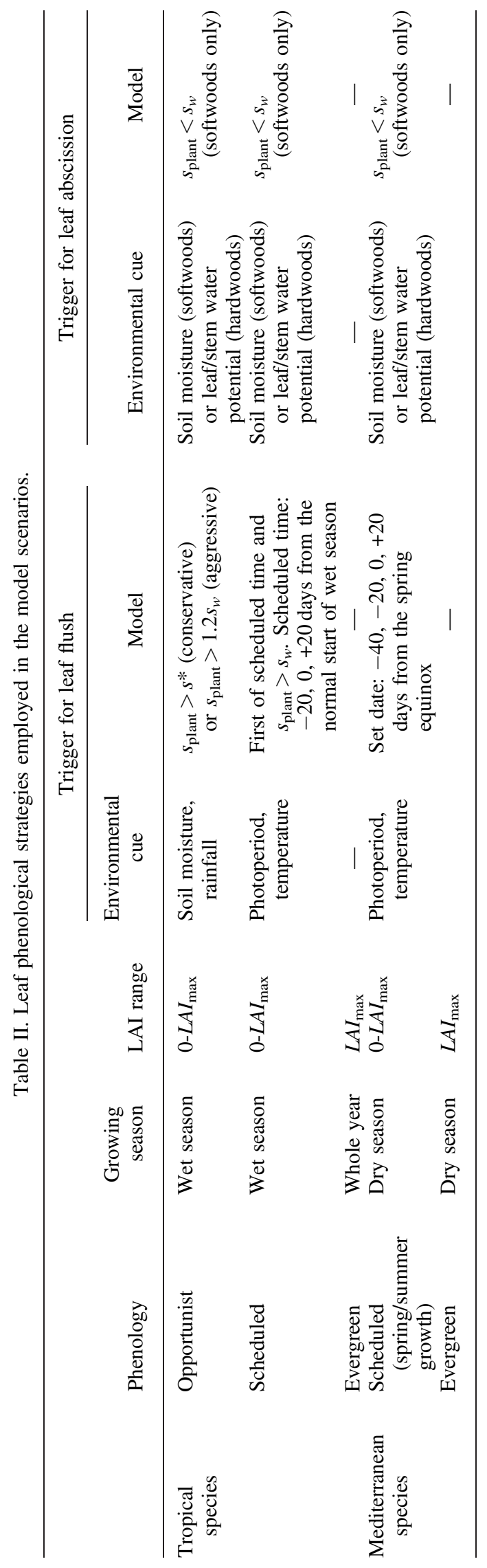

Ecohydrol. (2014) 
Brevi-deciduous and leaf-exchanging species can also be considered opportunistic, because the timing of leaf flushing seems to depend on local water availability. These species tend to occupy wet niches, with year-round access to rainfall-independent water stores. Leaf abscission occurs early in the dry season, in response to lowered hydraulic and photosynthetic efficiency and increased water stress in older leaves and is often followed by an increase in stem water potential, consistent with water uptake from deep soil stores (Jackson et al., 1995). Although the exact timing varies with local water availability, leaf flushing typically occurs less than a month after abscission, so that brevideciduous and leaf-exchanging species are to all effects near-evergreen.

Scheduled drought-deciduous species. Scheduled droughtdeciduous species share similar leaf abscission cues with opportunistic species, but their leaf flushing behaviour is largely independent of rainfall or water status, as also evidenced by lack of response to irrigation. Instead, these species flush their leaves in response to predictable environmental cues such as photoperiod, temperature, insolation (Wright and Cornejo, 1990; Myerscough and Murray, 1992) or the decrease in VPD associated with the 'build up' before the Northern Australian summer monsoon (Duff et al., 1997; Do et al., 2005). Scheduled flushing occurs in both tropical and Mediterranean climates (Penuelas et al., 2002; Rivera et al., 2002). Ecosystems dominated by scheduled flushing species exhibit a higher degree of interspecific synchrony and a lower inter-annual variability in flushing dates than those dominated by opportunistic species.

Many scheduled species have access to additional, persistent water stores (e.g. groundwater) or rely on the combination of multiple flushing cues to reduce the risks associated with the unpredictable timing of the wet season onset. For example, in an Asian monsoon forest with deep soils, most large (and presumably deep-rooted) trees exhibited photoperiod-driven flushing (Elliott et al., 2006). Some Mediterranean species schedule leaf flushing based on both winter rainfall totals and spring temperature (Penuelas et al., 2004). Also, a second, opportunistic flush following the onset of the rainy season may occur - a strategy that may limit the negative effects of herbivory (see Section on Non-Ecohydrological Drivers of Leaf Phenology).

Evergreen species. Evergreen species shed and regrow their leaves asynchronously throughout the year, so that no substantial seasonality is apparent in their leaf area index (LAI). Although evergreen species need to endure periods of water shortage, the extent to which they display physiological adaptations to minimize water loss is unclear (Borchert, 1994; Nepstad et al., 1994; Lima and Rodal, 2010; Markesteijn et al., 2011), as discussed in the next section.

\section{Ecophysiological adaptations}

The extent to which climatic variability impacts plant transpiration and photosynthesis is mediated by plant ecophysiological traits. A set of coordinated functional traits (xylem and stomatal conductances and water potential thresholds; photosynthetic capacity) and plant morphological characteristics (root, sapwood, and LAI) control water transport and transpiration (Tyree and Ewers, 1991; Manzoni et al., 2013). In this section, on the basis of a synthesis of published studies on $\sim 400$ species, we assess if these traits, and therefore transpiration rate and its relation to soil moisture, covary with the phenological strategies (see Figure 3 and the Supplementary material for details).

Root systems. Laterally extensive and deep root systems exploit soil water efficiently. Compared with droughtdeciduous species, evergreen species might require deeper roots to sustain water uptake during the dry season (Sobrado, 1986; Canadell et al., 1996; Eamus and Prior, 2001). Indeed, there are also some indications that rooting architecture depends on leaf phenology: tap roots tend to be more prevalent in evergreen species, whereas more distributed rooting systems are typical of deciduous trees (Scholz et al., 2008). However, rooting depth does not always follow leaf phenology (Franco et al., 2005; Miranda et al., 2010) and some evergreen species have been shown to utilize water from shallower soils than deciduous species (Jackson et al., 1999; Goldstein et al., 2008).

Plant hydraulic traits and regulation of transpiration. The maximum measured stomatal conductance, $g_{s, \max }$, is a proxy of the transpiration rate per unit leaf area under favourable VPD and water availability. Observed $g_{s, \max }$ values tend to be lower in evergreen species than in drought-deciduous ones in both tropical and Mediterranean SDEs (Figure 3A). The rate of transpiration in well-watered conditions follows a similar pattern across leaf habits for a given VPD and LAI.

As soil moisture decreases, stomatal conductance and hence transpiration per unit leaf area are reduced. The timing of stomatal closure depends on the balance of water supply to the leaves through the soil-plant system and water evaporation from the leaves. As soil dries, the water supply decreases because of reductions in both soil-root and plant xylem conductances; therefore, stomata conductance needs to decrease to avoid excessively negative leaf water potentials. Two stomatal strategies bound the spectrum of observed strategies: (i) an early stomatal closure during the dry period, so that high leaf water potential values can be maintained and the plant avoids water stress at the expense of lower $C$ uptake; and (ii) a late stomatal closure, which results in more negative xylem and leaf water potentials that may lead to cavitation and metabolic limitations to photosynthesis. Different hydraulic traits correspond to these stomatal regulation strategies (e.g. Manzoni et al., 2014). 

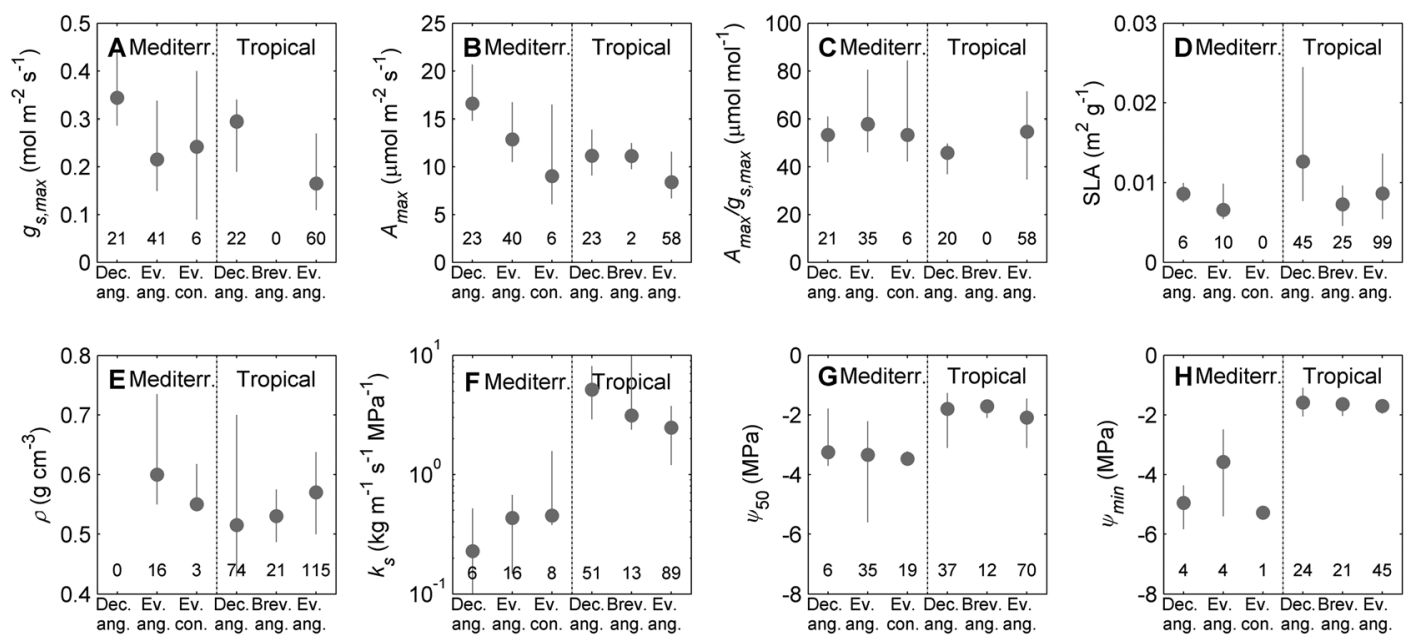

Figure 3. Relationship between ecophysiological traits and leaf phenological strategy in woody species from SDEs: (A) maximum stomatal conductance to water vapour (as measured at moderate vapour pressure deficits and moisture deficit); (B) light-saturated photosynthesis under well-watered conditions; (C) ratio between maximum photosynthesis and stomatal conductance, a proxy of leaf-level water use efficiency; (D) specific leaf area; (E) wood density; (F) sapwood-specific saturated hydraulic conductivity of the stem or branches; (G) water potential at $50 \%$ cavitation; and $\mathrm{H}$ ) minimum leaf water potential measured in dry conditions, for deciduous, brevi-deciduous and evergreen ('Dec', 'Brev', and 'Ev' for brevity), angiosperms ('ang'), and conifers ('con'). Circles and bars indicate median values and first and third quartiles, respectively; the number of data points used is also reported for each group; data relative to Mediterranean deciduous species include both winter and summer deciduous leaf habits; data have been collected from several published sources (see Supplementary Materials for details).

Early stomatal closure, drought avoidance, and nearly constant leaf water potential (i.e. an isohydric behaviour) are associated to higher water transport efficiency (low wood density, $\rho$, and high saturated xylem conductivity, $k_{s}$; Figure $3 \mathrm{E}$ and $\mathrm{F}$ ). These hydraulic features allow a smaller water potential gradient between the soil and the leaves for a given stomatal conductance and thus a less negative leaf water potential (Figure 3H), despite the fact that $k_{s}$ is often negatively correlated with resistance to cavitation (water potential at $50 \%$ loss of conductivity, $\psi_{50}$; Figure $3 \mathrm{G}$ ). Early stomatal closure is often observed in tropical SDEs (Meinzer et al., 1999; Bucci et al., 2004; Bucci et al., 2005; Goldstein et al., 2008). In contrast, most Mediterranean species have low hydraulic efficiency and maintain relatively high stomatal conductance during the dry season, providing higher potential $\mathrm{CO}_{2}$ uptake at the expense of lowered leaf water potentials (i.e. anisohydric behaviour; Figure 3G and H) (Sobrado, 1993b; Eamus and Prior, 2001; Franks et al., 2007; Miranda et al., 2010; Quero et al., 2011). Under such conditions, substantial cavitation and metabolic limitations to photosynthesis may occur (Xu and Baldocchi, 2003; Galmes et al., 2007). Mediterranean species may be forced to adopt this strategy (together with strong drought resistance) because their growing season, as defined by adequate temperature and solar radiation, often coincides with the dry season.

As apparent in Figure 3, these patterns across climates appear stronger than the pattern across leaf habits within a single climatic zone. Drought-deciduous species in tropical SDEs tend to maximize transport efficiency during the wet season (avoiding cavitation by dropping their leaves), while evergreen species are more conservative in their water use, with low conductance and high wood density (Sobrado, 1993a; Eamus and Prior, 2001; Chen et al., 2009; Miranda et al., 2010; Fu et al., 2012). However, leaf phenological strategy does not map closely to hydraulic traits; rather, water use strategies, xylem conductivities, resistance to cavitation, and minimum leaf water potentials overlap substantially across leaf habits (Figure 3F-H) (Borchert, 1994; Brodribb et al., 2002; Bucci et al., 2004; Santiago et al., 2004; Goldstein et al., 2008; Meinzer et al., 2008; Ishida et al., 2010; Markesteijn et al., 2011). A similar lack of consistent variation across phenological strategies is apparent in Mediterranean climates.

Photosynthetic rate, water use efficiency, and specific leaf area. Evergreen species are known to have lower photosynthetic rates on a per leaf mass basis (Eamus and Prichard, 1998; Eamus and Prior, 2001; Wright et al., 2004; Franco et al., 2005). Contrasting with previous reports (Eamus and Prior, 2001; Cianciaruso et al., 2013), we found the same pattern both in Mediterranean and tropical SDE also when expressing photosynthetic rates on a leaf area basis (Figure 3B). Nevertheless, because of a similar pattern in maximum stomatal conductance across leaf habits, the intrinsic water use efficiency $\left(A_{\max } / g_{s, \max }\right)$ depends only weakly on leaf phenology (Figure 3C).

Finally, the specific leaf area (leaf area per unit leaf dry weight, SLA; Figure 3D) is generally higher in droughtdeciduous than evergreen species, in agreement with most previous observations (Sobrado, 1986; Franco et al., 2005; but see also Brodribb and Holbrook, 2005). 


\section{MODELLING FRAMEWORK}

The joint effects of physiological and phenological strategies ultimately define transpiration and $\mathrm{C}$ gain, thus linking the climatic variability to plant fitness and determining the suitability of different strategies to a given climate. A minimalist model describing the coupled soil water and plant $\mathrm{C}$ balance is employed here to describe these linkages. Climate and plant parameters are based on the previous analysis of climatic regimes (Section on Precipitation Forcing) and synthesis of ecophysiological traits (Section on Vegetation Adaptation Strategies). Although this framework undoubtedly simplifies both plant responses to environmental conditions and soil and plant water dynamics, it preserves the key interactions between climate, soils, and vegetation while requiring few physically based parameters. Our aim with this modelling analysis is to assess which phenological strategies are most effective in a given climate. Additional factors potentially influencing phenological strategies, but not included in the model, are discussed in Section on Non-Ecohydrological Drivers of Leaf Phenology.

\section{Soil moisture balance}

In the absence of parenchymatic storage, plant-available water is mainly driven by the dynamics of soil water within the rooting zone. Plant roots span both shallow soil layers and deeper, more persistent water stores that may be partially decoupled from seasonal variations in rainfall (e.g. groundwater) and that could sustain plant activity in rainless periods. At daily time scales, the total plant-available soil water per unit ground area can thus be described by two coupled mass balances, representing the temporal evolution of the soil moisture $s_{1}(t)$ averaged over the top layer of depth $Z_{r, 1}$, and the soil moisture $s_{2}(t)$ within an additional water store of depth $Z_{r, 2}$ (as e.g. in Yu and D'Odorico, 2014):

$$
\left\{\begin{array}{l}
n Z_{r, 1} \frac{d s_{1}(t)}{d t}=R(t)-T_{1}\left(s_{1}, s_{2}\right)-E\left(s_{1}\right)-L_{1}\left(s_{1}\right) \\
n Z_{r, 2} \frac{d s_{2}(t)}{d t}=L_{1}\left(s_{1}\right)+I(t)-T_{2}\left(s_{1}, s_{2}\right)-L_{2}\left(s_{2}\right)
\end{array}\right.
$$

Soil in both water stores is assumed to have porosity $n$. Rainfall $R(t)$ represents the main input to the system, enhancing soil moisture in the top layer. Losses from the shallow layer occur via plant water uptake, $T_{1}\left(s_{1}, s_{2}\right)$, soil water evaporation, $E\left(s_{1}\right)$, and deep percolation, $L_{1}\left(s_{1}\right)$. The latter term represents the main input to the deep store, possibly complemented by a rainfall-independent deep recharge $I(t)$. Losses from the deep water store occur through plant water uptake $T_{2}\left(s_{1}, s_{2}\right)$ and deep percolation $L_{2}$ $\left(s_{2}\right)$. In both layers, percolation is assumed to occur instantaneously whenever the soil moisture of the corresponding layer exceeds a threshold $s_{\max }$ around the field capacity (Milly, 2001; Porporato et al., 2004; Vico and Porporato, 2010). Soil water evaporation is a piecewise linear function of $s_{1}(t)$, with maximum soil water evaporation $E_{\max }$ when $s_{1} \geq s_{w}, E_{\max } s_{1} s_{w}^{-1}$ otherwise. We note that averaging soil moisture over a water store implicitly accounts for the hydraulic redistribution within that soil volume - a phenomenon observed in some SDE species (Kurz-Besson et al., 2006; Scholz et al., 2008; Prieto et al., 2010; Neumann and Cardon, 2012). However, hydraulic redistribution between the two soil water stores is neglected.

Total plant water uptake from both stores is determined by plant transpiration demand, a function of atmospheric VPD, $D$, plant size (as described by LAI, $L A I(t)$ ), and stomatal conductance to water vapour, $g_{s}(t)$,

$$
T_{\text {tot }}=g_{s}(t) D(t) L A I(t) .
$$

To capture the separate effects of VPD and soil moisture, stomatal conductance is described as $g_{s}(t)=g_{w w}(D) f_{s}\left(s_{\text {plant }}\right)$, where $g_{w w}(D)$ is the stomatal conductance under wellwatered conditions and the function $f_{s}\left(s_{\text {plant }}\right)$ accounts for the effect of 'plant-sensed' soil water in reducing the effective stomatal conductance from its well-watered level, by lumping plant hydraulic traits in a single 'effective' function (see Buckley (2005) for a review of more mechanistic approaches). The plant-sensed soil moisture $s_{\text {plant }}$ is defined as $s_{\text {plant }}=\max \left[s_{1}, s_{2}\right]$, assuming that leaf-level activity is driven by the highest soil moisture between the two compartments. This assumption is supported by the observation of high stomatal conductance during the dry season in trees that have access to deep water stores (David et al., 2007; Miller et al., 2010) as well as by localized irrigation experiments (Green et al., 1997; Kang et al., 2003; Guswa, 2012). The stomatal conductance under well-watered conditions is assumed to depend on $D$ as $g_{w w}(D)=g_{s, \max }(1-m \ln D)$, with $g_{s, \max }$ corresponding to a reference stomatal conductance at $D=1 \mathrm{kPa}$ (Oren et al., 1999), here approximated by the maximum measured stomatal conductance (Figure 3A). As a first approximation, the effect of soil moisture can be summarized by considering that, for given $D$, transpiration proceeds unhampered when the available plant-sensed soil moisture, $s_{\text {plant }}$, is above a threshold $s^{*}$, and is linearly reduced when water is in scarcer supply,

$$
f_{s}\left(s_{\text {plant }}\right)=\left\{\begin{array}{cc}
\frac{s_{\text {plant }}}{s^{*}} & s_{\text {plant }}<s^{*} \\
1 & s_{\text {plant }} \geq s^{*}
\end{array}\right.
$$

The threshold $s^{*}$ is the soil moisture availability corresponding to incipient stomatal closure and captures the response of stomatal conductance (and hence transpiration per unit leaf area) to reduced soil water availability, thus lumping the effect of changes in soil water content on leaf-level activity as mediated by plant hydraulics. On the basis of the synthesis of the physiological traits (Section on Plant Hydraulic Traits and Regulation of Transpiration), a single function, $f_{s}\left(s_{\text {plant }}\right)$, and threshold, $s^{*}$, common to all functional types, is employed.

Assuming that the water stored in plant tissues is in equilibrium (i.e. neglecting water stored in plant parenchyma), 
the water uptake from the soil, the flux through the stem, and the plant level transpiration are all equal. Hence, the water uptake demand set in Equation (2) must be met by total plant water uptake from the two water stores, $T_{1}\left(s_{1}, s_{2}\right)$ and $T_{2}$ $\left(s_{1}, s_{2}\right)$. The two water stores are assumed to contribute to meet plant water demand proportionally to their own soil water content and the fraction of roots located in each one,

$$
\begin{aligned}
& T_{1}\left(s_{1}, s_{2}\right)=T_{t o t} \frac{\alpha s_{1}}{\alpha s_{1}+(1-\alpha) s_{2}} \\
& T_{2}\left(s_{1}, s_{2}\right)=T_{t o t}\left(s_{1}, s_{2}\right)-T_{1}\left(s_{1}, s_{2}\right),
\end{aligned}
$$

where $\alpha$ is the fraction of total root biomass located in the top compartment. It follows that, for set root distribution, the plant depletes faster the compartment with higher water availability. Should roots be completely located in the shallower layer (i.e. $\alpha=1$ ), plant transpiration would be driven by the soil moisture on the top layer only (i.e. $\left.s_{\text {plant }}=s_{1}\right)$ and all the water uptake would occur from the top layer $\left(T_{1}\left(s_{1}, s_{2}\right)=T_{t o t}\right)$. Water uptake by nearby competing vegetation (non-beneficial losses at the individual plant level) are neglected: these additional losses would not significantly alter the results as they would act in similar ways under all climates.

\section{Carbon economy}

When assessing the long-term $\mathrm{C}$ economy of evergreen and deciduous leaf habit, several factors should be considered: (i) the higher photosynthetic rate in deciduous species leaves is counterbalanced by their shorter lifespan (Wright et al., 2004; Mediavilla et al., 2008; van Ommen Kloeke et al., 2012); (ii) the leaf construction costs are lower in deciduous species due to their larger SLA; (iii) leaf respiration during the dry, unfavourable season negatively affects only the evergreen species; and (iv) although rooting morphology appears to only partially map onto leaf habit (see Section on Root Systems), root-associated costs are generally assumed higher for the evergreen species because they need to maintain leaf hydration throughout the year (Givnish, 2002). Here, we consider factors i-iii based on leaf habit-specific data from Figure 3 and other sources, whereas root allocation and depth are varied independently of leaf habit.

To proceed quantitatively, a minimalist $\mathrm{C}$ balance is employed, representing the annual $\mathrm{C}$ gain per unit ground area, $G$, with input from $\mathrm{C}$ fixation via photosynthesis, $G_{\text {gross }}$, and losses occurring via maintenance respiration, $R_{m}$, and leaf construction costs, $c$ :

$$
\begin{aligned}
G & =G_{\text {gross }}-R_{m}-c \\
& =\int_{\text {year }} \eta_{A} A(t) L A I(t) d t-\int_{\text {year }} r L A I(t) d t-f_{\text {flush }} f_{C} \frac{L A I_{\max }}{S L A} .
\end{aligned}
$$

In (5), $A(t)$ and $r$ are the leaf-level photosynthetic and maintenance respiration rates, expressed on a per unit leaf area basis, $L A I(t)$ is the LAI (which changes in time between 0 and $L A I_{\max }$, see Section on Representation of Phenological Strategies), $\eta_{A}$ accounts for the carbon use efficiency and the reduced light availability early in the morning and late in the day, $f_{\text {flush }}$ is the frequency of leaf flushing (i.e. the number of flushing occurring over the year), $f_{C}$ is the fraction of $\mathrm{C}$ per unit leaf mass, and $S L A$ is the specific leaf area. Using a linearized photosynthesis model and neglecting the $\mathrm{CO}_{2}$ compensation point, the leaf-level photosynthetic rate can be estimated as (Hari et al., 1986; Manzoni et al., 2011)

$$
A(t)=\frac{k(T) c_{a} g_{s}(t)}{g_{s}(t)+a k(T)},
$$

where $c_{a}$ is the atmospheric $\mathrm{CO}_{2}$ concentration, $g_{s}(t)$ is the stomatal conductance to water vapour, $a=1.6$ is the ratio between the diffusivities of water vapour and $\mathrm{CO}_{2}$ in air, $k(T)$ is a macroscopic kinetic constant, accounting for the metabolic capacity and how it is affected by temperature $T$ and light availability. Neglecting light limitations, it can be shown that $k(T) \cong V_{c \max }(T)\left[r_{C} c_{a}+K_{c}(T)\left(1+o_{a} K_{o}(T)^{-1}\right)\right]^{-1}$, where $V_{c \max }$ is the maximum carboxylation rate, $r_{C}$ is the long-term average ratio between stomatal and atmospheric $\mathrm{CO}_{2}$ concentrations, $K_{c}$ and $K_{o}$ are the Michaelis-Menten constants for $\mathrm{CO}_{2}$ fixation and oxygen inhibition, and $o_{a}$ is the oxygen concentration in the air. Employing the temperature dependences of Bernacchi et al. (2001), $k(T)$ increases linearly with temperature in the temperature range typical of the considered sites and can be modelled as $k(T) \cong k_{25}$ $(0.03 T+0.25)$, where $k_{25}$ is the macroscopic kinetic constant at $25^{\circ} \mathrm{C}$ - the only kinetic parameter to be estimated. When stomatal conductance is high, assimilation rate is not limited by $\mathrm{CO}_{2}$ availability and $A \cong k c_{a}$, so that $k_{25}$ can be estimated as $k_{25}=A_{\max } c_{a}^{-1}$ (implicitly assuming that the assimilation rates where collect at about $25^{\circ} \mathrm{C}$ and ambient $c_{a}$ ). The obtained photosynthetic rate is further reduced to account for daily changes in light availability. In contrast, the decline in photosynthetic efficiency with leaf age is neglected, potentially overestimating total $\mathrm{C}$ fixation, particularly in evergreen species.

The C loss terms in Equation (5) are estimated as follows. Maintenance respiration rate per unit leaf area is assumed to be equal to a fraction $f_{\text {resp }}$ of the maximum $\mathrm{C}$ assimilation rate, $A_{\max }$, i.e. $r=f_{\text {resp }} A_{\max }$ (Givnish, 2002), thus resulting in a higher respiration rate per unit leaf area in deciduous species. Leaf construction costs per leaf mass are independent of leaf habit (Eamus and Prichard, 1998), but construction cost per unit ground area vary with leaf phenology. Evergreen species have lower SLA than deciduous species (Figure 3D), resulting in higher construction costs for a given $L A I_{\max }$. However, evergreen leaves may have lifespans extending beyond 12 months, so 
that the frequency of leaf flushing, $f_{\text {flush }}$, is lower than in drought-deciduous species. Potential additional costs stemming from water shortage (e.g. xylem refilling after cavitation; osmolyte production to maintain leaf turgor) are neglected.

\section{Model parameterization}

Plant functional type impacts water and $\mathrm{C}$ balances primarily through two mechanisms: (i) ecophysiological traits that regulate water losses and $\mathrm{C}$ uptake at the leaf level and (ii) changes in LAI that affect the timing and rates of transpiration and $\mathrm{C}$ exchanges at the whole plant level. Here, the representation of these mechanisms in the model and the necessary climatic data are discussed.

Representation of phenological strategies. Phenological variations are coupled to the soil water and plant $\mathrm{C}$ balances framework by allowing changes in time of the LAI. We treat evergreen species as having a constant LAI, equal to a preset $L A I_{\max }$, regardless of water availability. Conversely, the time variation of LAI for droughtdeciduous species is idealized as a step increase from zero to $L A I_{\max }$ at leaf flushing, whereas leaf abscission is assumed to occur more gradually, with a rate depending on soil water availability. The dates of leaf flushing are determined differently for tropical and Mediterranean SDEs, while leaf abscission is modelled in the same way in both ecosystems and for both opportunistic and scheduled species, as detailed next and summarized in Table II. Treating leaf flushing as an instantaneous process may overestimate transpiration for species that complete leaf extension gradually (e.g. Reich, 1995; Lima and Rodal, 2010) but is an effective way to capture the main patterns in water use across SDEs.

Leaf flushing: For tropical opportunistic species, the leaf flush date is assumed to be a function of the plant-sensed soil moisture, $s_{\text {plant }}$ (as defined in Section on Soil Moisture Balance). Flushing is triggered by soil water availability crossing the threshold, $s_{\text {flush }}$ (sensu Yoshifuji et al. (2011)). Two soil water availability thresholds triggering leaf flushing are considered (Table II). The more conservative species flush their leaves when the soil is wet enough to allow full stomatal opening, i.e. $s_{\text {flush }}=s^{*}$. Aggressive species flush their leaves as soon as the soil water availability exceeds a lower threshold, $s_{\text {flush }}=1.2 s_{w}$, where $s_{w}$ is the soil moisture at the wilting point and $s_{w}<s_{\text {flush }}<s^{*}$.

For tropical scheduled species, leaf flush is idealized as occurring on a set date - as if plants responded to photoperiod only (Table II). Conservative scheduled species flush their leaves after the 'normal' beginning of the wet season. Aggressive scheduled species flush their leaves before the beginning of the wet season. Three leaf flushing dates are explored, 'early', 'normal', and 'late', referring to species flushing their leaves respectively 20 days before, at, and 20 days after the 'normal' beginning of the wet season. The 'normal' beginning of the wet season is defined as the average date on which the 20th percentile of annual total rainfall is reached; hydrologic year is treated as starting at the end of the driest month. We allowed for leaf flush in scheduled species to be deferred in abnormally dry years until the soil water content reaches at least $s_{w}$ but did not consider multiple leaf flushes in a single growing season (e.g. in response to damage inflicted by a delayed wet season onto previously flushed leaves).

In Mediterranean SDEs, spring/summer growing species exploit soil water accumulated during the wet winter and have scheduled leaf flushing in the early spring driven by photoperiod or temperature cues. Here, we focus on photoperiod-driven species and consider different dates for leaf flushing with respect to the spring equinox, thus covering a wide range of dates (from 40 days before the equinox to 20 days after that), following the observations of Penuelas et al. (2002) for North-Eastern Spain. Non-woody opportunistic species growing in the wet fall/winter are not included.

Leaf abscission: Regarding leaf abscission, only softwood species are considered in both tropical and Mediterranean SDEs. In these species, leaf abscission is initiated when available soil water declines below an abscission threshold, for simplicity set at the wilting point $s_{w}$. In agreement with observations (e.g. Valdez-Hernandez et al., 2010) and earlier models (Arora and Boer, 2005), leaf abscission rate is assumed to accelerate as soil moisture drops below $s_{w}$, and to be interrupted when rainfall brings soil moisture back to values above $s_{w}$ (although the previously lost leaves are not restored), i.e.

$$
\frac{d L A I(t)}{d t}=\left\{\begin{array}{cc}
0 & s_{\text {plant }}>s_{w} \\
-L A I(t) \beta_{a b s c}\left[s_{w}-s_{\text {plant }}(t)\right] & s_{\text {plant }} \leq s_{w}
\end{array},\right.
$$

where the higher the constant $\beta_{a b s c}$, the faster the decline.

Describing leaf abscission in hardwood species would require describing the temporal evolution of their stem water storage, which lies beyond the scope of this work. Qualitatively, for a given leaf flushing strategy and water availability, hardwood species will have longer leaf lifespans than softwood ones.

Rooting systems and deep water storage. To elucidate the effects of rooting depth and rainfall-independent groundwater recharge on the optimal leaf strategy, both shallow rooting systems $\left(\alpha=1, s_{\text {plant }}=s_{1}\right)$, and plants with access to deep water stores $\left(\alpha<1, s_{\text {plant }}=\max \left[s_{1}, s_{2}\right]\right)$ are explored. In the latter case, the effect of groundwater recharge is also considered $(I=0$ vs $I>0)$. In each scenario, the rooting depths and distribution $\left(Z_{r, 1}, Z_{r, 2}\right.$, and $\left.\alpha\right)$ are maintained 
constant across plant functional types and sites. We assume that the dry seasons are long enough for water availability in the active rooting zone at beginning of the hydrologic year to be independent of the rainfall occurrence and plant activity during the previous year, so that subsequent years may be considered as independent.

Ecophysiological parameters. Plant water use strategy impacts primarily the maximum stomatal conductance, $g_{s, \max }$, and maximum assimilation rate, $A_{\max }$, and, to a lesser extent, specific leaf area, $S L A$ (Figure 3). In the model, these parameters are set equal to the median of the observed values (circles in Figure 3; for evergreen species, only angiosperms are considered). Conversely, the soil moisture threshold for incipient stomatal closure, $s^{*}$, is assumed to be invariant with functional type, because of the weak dependence of hydraulic traits on phenological strategy. Moreover, to facilitate the comparison among different climates, the analyses are conducted assuming a 'prototype' species, i.e. keeping the peak LAI $\left(L A I_{\max }\right)$, and the abscission rate coefficient $\left(\beta_{a b s c}\right)$ constant across functional types and climates.

Climatic forcing. The model is forced with historical rainfall data from the five case study sites (Figure 1; Table I). Because data on air humidity and temperature were not available for all locations, the seasonal evolution of VPD is idealized as a sinusoidal curve, with $D(t)$ reaching its minimum, $D_{\text {wet }}$, during the wettest month, and its maximum, $D_{\mathrm{dry}}, 6$ months later; the daily temperature was reconstructed by fitting a sinusoidal function to the monthly average temperatures (Figure 1). While using longterm average temperatures does not account for the interannual variability, it does incorporate the negative effects of winter conditions on the $\mathrm{C}$ assimilation of Mediterranean evergreens.

\section{QUANTITATIVE ASSESSMENT OF PHENOLOGICAL STRATEGIES}

For each site and phenological strategy, the model provides the temporal evolution of soil moisture, stomatal conductance, and LAI. It is then possible to determine the flushing date and leaf duration, total seasonal transpiration and $\mathrm{C}$ gain, and how they vary from year to year in different climates and for different plant functional types. As such, the model results allow quantifying the effects of the intraannual and inter-annual variability in rainfall patterns apparent in Figure 2. The following sections present such results for the five study sites and compare them with observations available in the literature.

\section{Temporal evolution of soil moisture, transpiration, and leaf area index}

Figure 4 shows an example of the modelled temporal evolution of LAI, water uptake and available soil water, for
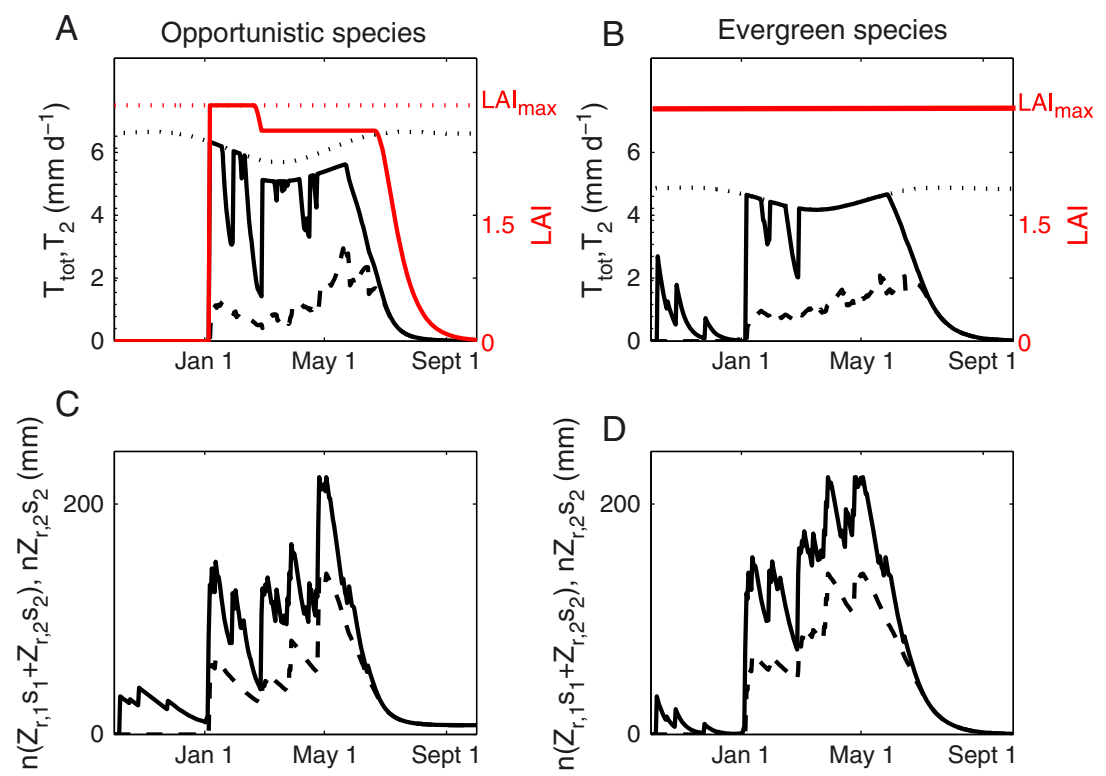

Figure 4. Example of the temporal evolution of (A,B) transpiration and LAI (black and red lines respectively) and (C,D) soil water availability for opportunistic species (left) and evergreen species (right), relative to year 1939-1940 in Santa Terezinha, assuming access to a deep water store of capacity $n Z_{r, 2}$. In all panels, black solid lines refer to transpiration and soil water totals and dashed lines to the contribution of the deeper water store ( $T_{2}$ and $n Z_{r, 2} s_{2}$ ). In (A,B), the actual transpiration rate $T_{\text {tot }}$ (solid black line) is compared with the corresponding transpiration rate under well-watered conditions (dotted black line), the actual LAI (solid red line) to the peak LAI, $L A I_{\max }$ (dotted red line). Other parameters are: $Z_{r, 1}=0.3 \mathrm{~m}, Z_{r, 2}=0.5 \mathrm{~m}$, $\alpha=0.7$; soil is sandy loam $\left(n=0.43, s_{w}=0.18, s^{*}=0.46, s_{\max }=0.65\right.$; Laio et al., 2001), $m=0.6$ (Oren et al., 1999$), D_{\mathrm{wet}}=1 \mathrm{kPa}, D_{\mathrm{dry}}=2.2 \mathrm{kPa}$, $L A I_{\max }=3, E_{\max }$ is $10 \%$ of the total transpiration under well-watered conditions and maximum LAI, and $\beta_{a b s c}=0.4 \mathrm{~d}^{-1}$; $g_{s, \text { max }}$ is set at the median of the data collected in Figure 3 (for the evergreens, only angiosperms are considered). 
deep-rooted opportunistic and evergreen species for a specific year in Santa Terezinha (Northeastern Brazil). Total soil water content (Figure 4 bottom) is driven by the occurrence of rainfall as well as by losses through transpiration, which in turn are impacted by water availability (Figure 4 top). Moreover, in drought-deciduous species (Figure $4 \mathrm{left}$ ), LAI is controlled by the water availability, which drives flushing and shedding dynamics (Figure 4A, red line). Thanks to the permanence of leaves, evergreen species are able to exploit water input regardless of its timing, although isolated events (such as the one occurring at the beginning of the hydrologic year in this example) cannot sustain long periods of high transpiration. This continuous uptake of water by evergreen species reduces peak transpiration rates with respect to droughtdeciduous species. At the same time, transpiration rates under well-watered conditions are lower in evergreens, a consequence of their lower $g_{s, \max }$ (Figure 3A). When combined, these mechanisms result in less abrupt changes in soil moisture in both compartments in the presence of evergreen species, while soil moisture tends to be accumulated before leaf flushing and then depleted faster in the presence of drought-deciduous species (compare Figure 4C with D).

Rainfall and water use patterns affect the recharge of and contribution from the two water stores. Regardless of vegetation type, deep store recharge occurs only as a consequence of rainfall events that are able to increase soil moisture in the top compartment above field capacity. Hence, with drought-deciduous species, deep store recharge occurs mostly at the beginning of the wet season and after leaf abscission, when the absence of leaves reduces transpiration. Furthermore, the water-richest compartment is exploited first, thus resulting in a faster depletion of its water content until the two moisture levels become similar. The water depletion is always fastest in the top layer, where most roots are located (in the example of Figure $4, \alpha=0.7$ ).

Figure 4 also shows the corresponding temporal evolution of LAI (red solid lines). The modelled LAI qualitatively matches observations in drought-deciduous species, with a sharp increase in leaf area following significant rainfall and a more gradual decline in LAI at the onset of the dry season (e.g. Valdez-Hernandez et al., 2010). This decline is slow at moisture level just below the threshold $s_{w}$, accounting for the plant ability to withstand brief periods of water stress, whereas the decline is faster for intermediate LAIs and soil moisture. If a rainfall event increases soil moisture above $s_{w}$ (e.g. the 1 March event in Figure 4), leaf abscission is temporarily halted, until soil water availability declines again (Equation (7)). Because it is assumed that previously lost leaves are not replaced, the transpiration and photosynthetic rates per unit ground area are reduced accordingly, regardless of any later rainfall occurrence.

\section{Timing of leaf flushing and leaf duration in drought-deciduous species}

The potential growing season for evergreen species spans the entire year. Conversely, the growing season of droughtdeciduous species is limited to the time in which leaves are present - the result of the combined effects of rainfall amount and timing, leaf phenological strategy, and ecophysiological traits. Here, we define the leaf duration and $\mathrm{C}$ fixation season for drought-deciduous species as the time between leaf flushing and leaf abscission (Table II). Because leaf abscission is a gradual process (Equation (7)), here we define abscission date as the day in which LAI is reduced to $L A I_{\max } / 4$ : although LAI may then remain at such level for a prolonged period if rainfall occurs, the water and $\mathrm{C}$ fluxes generated by such reduced LAI contribute little to the annual totals.

The high rainfall inter-annual variability in SDEs causes broad and often bimodal distributions of flushing and abscission dates, as illustrated in Figure 5A and B for Santa Terezinha. In scheduled species, the distribution of abscission dates is bimodal (Figure 5A). Flushing before or at the average onset of the main wet season results in extremely short growing periods when the onset of the wet season is delayed. Conversely, the same strategy is beneficial in those years when the wet season begins on its average date, permitting plant activity over a longer period. In opportunistic species, the flushing dates also vary from year to year (dot-dashed lines in Figure 5B), resulting in a unimodal distribution around the typical onset of the wet season (6 February in Santa Terezinha). Abscission dates exhibit a bimodal distribution similar to scheduled species, with a small peak immediately following the average beginning and a larger one following the end of the wet season. The former peak pertains to years in which the wet season is not consistently wet, causing early leaf loss. The patterns in Figure 5 are similar to those observed in other SDEs (Yoshifuji et al., 2011).

Leaf duration is also highly variable from year to year, with a bimodal distribution for all phenological strategies (Figure 5C and D). On average, scheduled normal flushing allows longer leaf durations than scheduled early and opportunistic flushing. In fact, in dry climates such as Santa Terezinha, aggressive strategies ('early' scheduled flushing or opportunistic flushing in response to small increases in soil water availability) are counterproductive, because water stress early in the wet season is likely. More conservative strategies, such as 'normal' scheduled species or opportunistic species with higher soil water thresholds, lead to the greatest leaf durations. With these strategies, the risk of damage if the wet season is delayed is reduced.

The impacts of the phenological strategies on leaf duration depend on climate and rooting depth. Examples of leaf duration distributions for scheduled species with different root depths are presented in Figure 6 for the cases of 

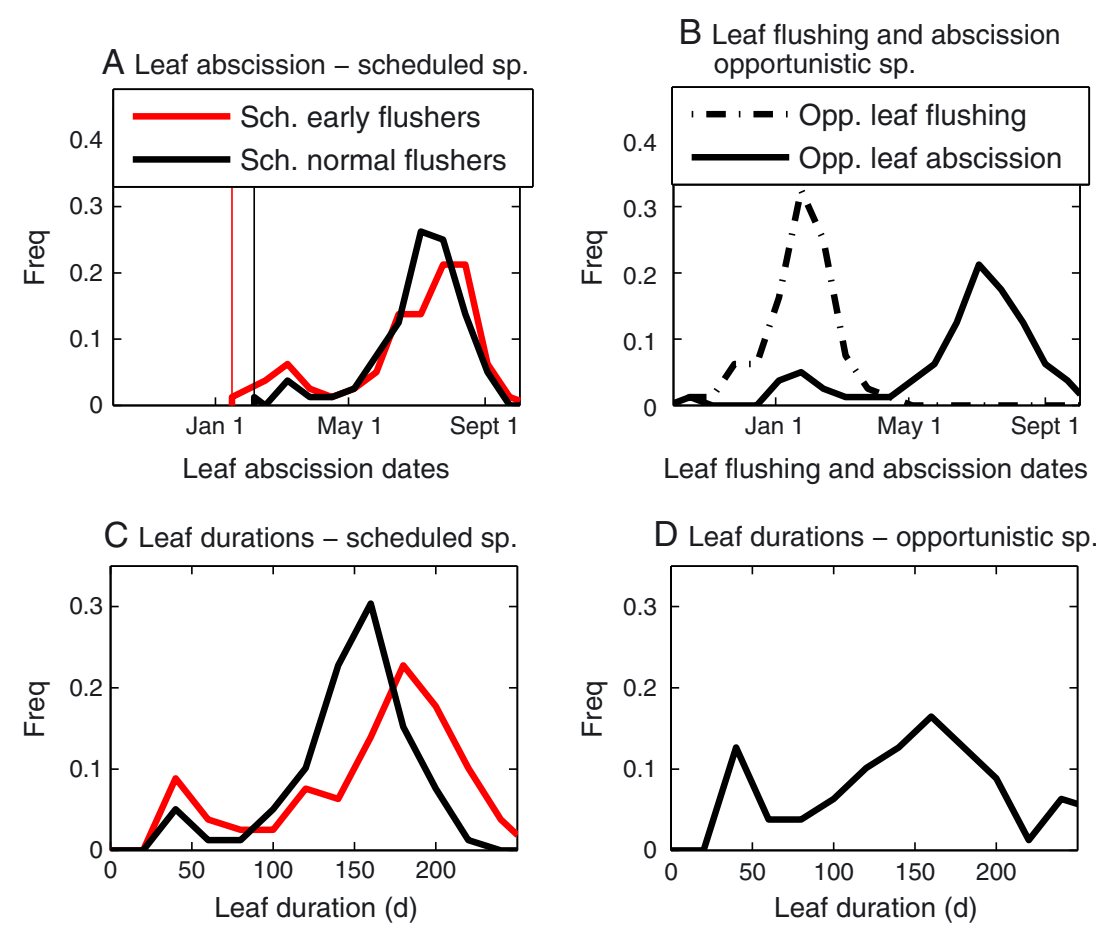

Figure 5. Frequency distributions of (A,B) leaf flushing and abscission date and (C,D) leaf duration, as a function of leaf flushing strategy (scheduled, left; opportunistic, right), for plants that have access to a deep water store of capacity $n Z_{r, 2}$. (A,C) refer to scheduled species, flushing their leaves on either 17 January (scheduled early flushers; red lines) or on 6 February (scheduled normal flushers; black lines). (B, D) depict the case of opportunistic species, flushing their leaves at $s_{\text {flush }}=s^{*}$. The vertical lines in A denote the flushing dates for scheduled early and normal flushers (red and black lines, respectively); the dot-dashed line in B represents the frequency distribution of the opportunistic flushing dates. Rainfall data refer to Santa Terezinha. All other parameters are as in Figure 4.
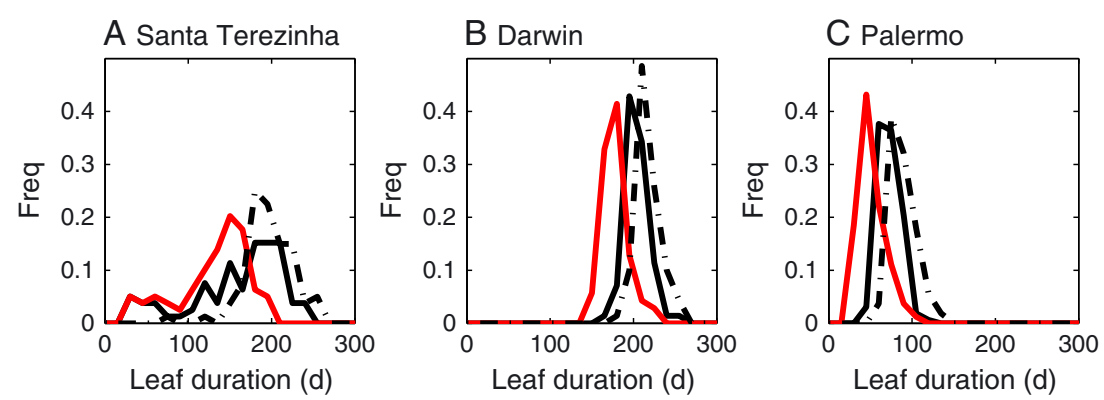

Figure 6. Frequency distributions of leaf durations in (A) Santa Terezinha (dry tropical SDE), (B) Darwin (wet tropical SDE), and (C) Palermo (Mediterranean SDE) for scheduled drought-deciduous species with shallow roots (red lines), and deep roots accessing the water store $n Z_{r, 2}$, without and with groundwater input (black solid and dot-dashed lines respectively). Leaf flushing occurs 20 days before the normal beginning of the wet season for tropical SDEs or before spring equinox for Mediterranean SDE. All other parameters are as in Figure 4.

Santa Terezinha, Darwin, and Palermo. In wetter climates like in Darwin, the risk of water shortage early in the wet season is reduced and leaf durations are correspondingly longer (compare Figure 6B with A and C). In tropical SDEs, the effect of rainfall amounts is compounded with interannual variability: the extreme variability in the rainfall amount and wet season timing at Santa Terezinha leads to a greater variability in leaf durations than in the Australian sites, characterized by higher rainfalls and smaller interannual variability (Figure 6A and B). Inter-annual variability in rainfall timing and amount is less relevant in spring flushing Mediterranean species. In Palermo, leaf abscission occurs early after the end of the wet season, resulting in a unimodal distribution of durations with low average (Figure 6C), while in Perth leaves may be sustained for longer periods in the wettest years, thus giving rise to a slightly bimodal distribution of leaf durations (not shown). Hardwood species (not considered here) may sustain leaves longer, potentially throughout the dry season, thus becoming winter-deciduous.

Rooting depth further alters the distribution of leaf abscission dates and durations. In general, the risk of water limitation immediately after leaf flushing is partially 
mitigated by access to deep water stores (Borchert and Rivera, 2001; Lima and Rodal, 2010), so that leaf durations become longer and more unimodally distributed (compare red with black lines in Figure 6A and B). Similarly, in Mediterranean climates, deep water stores allow larger water accumulation during the winter, yielding longer and slightly more variable leaf durations (Figure 6C).

\section{Effect of leaf strategy on water and carbon economies}

While useful when considering the timing of water use, leaf durations per se do not allow assessment of the best adapted phenological strategy for a given climate. Conversely, net annual $\mathrm{C}$ gain provides a metric by which all the phenological strategies, including evergreen habit, can be compared within a common framework.

Figure 7 summarizes net $\mathrm{C}$ gain achieved by each leaf phenological strategy in all case studies, for shallow-rooted plants (top), deep-rooted plants without rainfall-independent groundwater input (center; $I(t)=0$ ), and deep-rooted plants with groundwater input (bottom; $I(t)>0$ ). As expected, higher average rainfall input (from black to light grey symbols) enhances $\mathrm{C}$ gains for all phenological strategies and rooting depths. In tropical climates, the combined effects of lack of deep water stores and longer and more intense dry seasons, favour deciduous species. Indeed, drought-deciduousness is more common under climates with strong seasonality or with low rainfall during the dry season and is less related to total annual rainfall (Givnish, 2002; Bowman and Prior, 2005). As a result, in dryer climates, such as Santa Terezinha, drought-deciduousness is always beneficial, while in wetter climates (e.g. Darwin), a deeper rooting system is sufficient to make evergreen species competitive. Conversely, in Mediterranean ecosystems, evergreen habit confers a competitive advantage, thanks to the ability to exploit winter rainfall throughout the seasons, as opposed to just the accumulated water. Consistent with the results of the model, the highly variable South American caatinga (Sampaio, 1995) is dominated by drought-deciduous species (Machado et al., 1997; Lima and Rodal, 2010; Cabral et al., 2013), while the less climatically variable Australian tropics are predominantly evergreen (Hutley et al., 2001; Bowman and Prior, 2005; Lehmann et al., 2009). Finally, evergreen woody species are dominant in Mediterranean ecosystems (Cody and Mooney, 1978), despite the out-ofphase patterns in temperature, light, and water availability.

Among tropical drought-deciduous species, median C gain suggests that the most beneficial strategy is scheduled normal flushing in drier sites and where roots are shallow (strategy $\mathrm{N}$ in Figure $7 \mathrm{left}$ ), while in wetter locations $\mathrm{C}$ gain is maximized by opportunistic and early scheduled flushing (strategies $s^{*}$ and $\mathrm{E}$ in Figure 7 left). Indeed experimental observations in the Darwin area showed that $80 \%$ of the dominant species flushed leaves during the dry
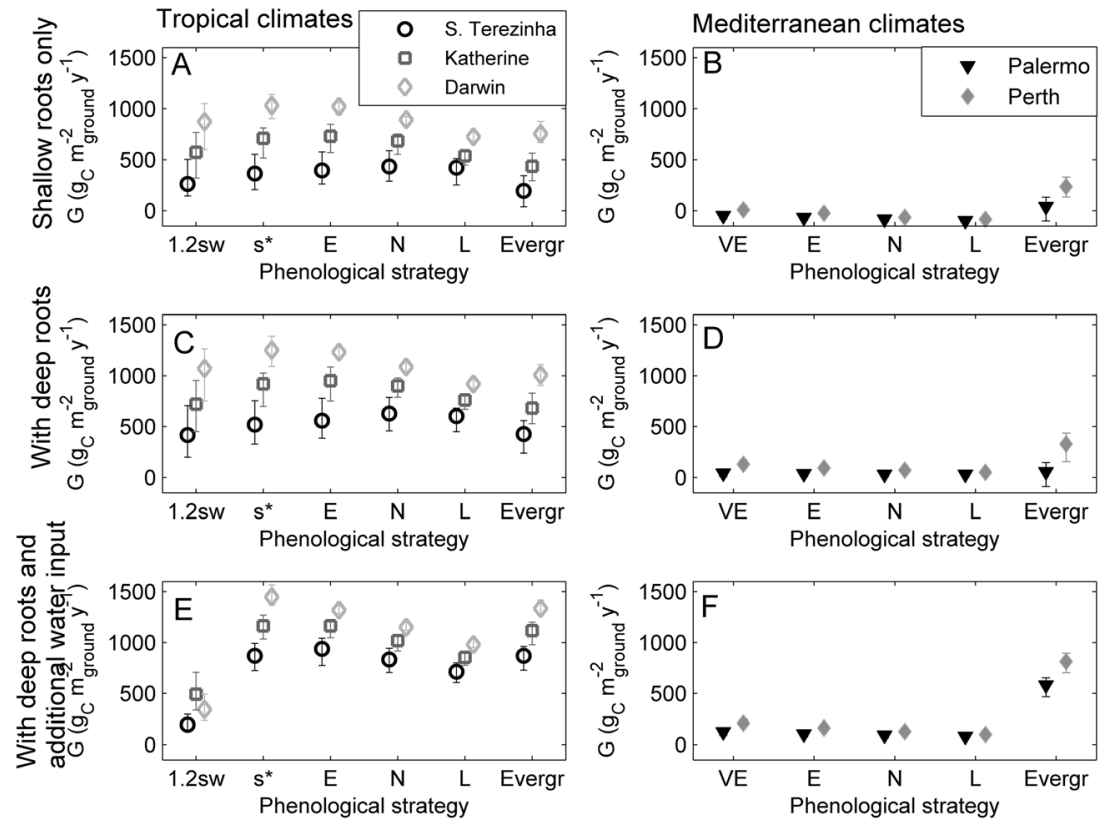

Figure 7. Median (symbols) and 25-75 percentiles (whiskers) of carbon gain $G$ as a function of phenological strategy and access to deep water stores, for (left) three contrasting tropical climates and (right) two Mediterranean climates (Table I, Figure 1). A and B refer to plants with shallow roots ( $\alpha=1)$. C-F refer to deep-rooted plants accessing the deep water store without $(I=0 ; \mathrm{C}, \mathrm{D})$, or with groundwater recharge $\left(I=0.5 \mathrm{~mm} \mathrm{~d}^{-1}\right.$; E,F). Opportunistic flushing is triggered at $s_{\text {flush }}=1.2 s_{w}$ and $s^{*}$. Scheduled flushing is defined with respect to typical onset of wet season in tropical regions or the spring equinox in Mediterranean climates (VE, 40 days earlier; E, 20 day earlier; N, at the onset of wet season/equinox; L, 20 days after). All the other parameters are as in Figure 4. Additionally, for the carbon balance, $f_{\text {resp }}=0.07, f_{C}=0.45, f_{\text {flush }}=1 \mathrm{y}^{-1}$ for drought-deciduous species and $0.67 \mathrm{y}^{-1}$ for evergreen species, $\eta_{A}=0.65, c_{a}=380 \mu \mathrm{mol} \mathrm{mol}^{-1}, a=1.6$, and $A_{\max }, g_{s, \max }$, and $S L A$ are the median of the data in Figure 4 (only angiosperms are considered). 
season, i.e. 'early' (Williams et al., 1997). Indian SDEs, which are affected by the Indian Ocean Monsoon like Northern Australian SDEs, also exhibit early scheduled flushing (1-2 months before the beginning of the wet season; Kushwaha and Singh, 2005) or opportunistic flushing triggered by pre-monsoonal rainfall events despite low soil water contents (Prasad and Hedge, 1986). The model results also show that shifting from opportunistic to normal and late scheduled strategies in Santa Terezinha increases the median leaf duration and $\mathrm{C}$ gain. The opposite trend holds in Darwin and Katherine, in particular in the presence of deep roots. These findings are consistent with the general phenological pattern suggested by Rivera et al. (2002), with photoperiod-driven leaf flushing often occurring where annual precipitation is above $800 \mathrm{~mm}$ (and the dry season lasts $4-6$ months) but rarely in the presence of lower annual rainfall (such as in Northeastern Brazil) or shorter dry seasons. In contrast to tropical ecosystems, in Mediterranean SDEs early or very early scheduled flushing (strategy VE and E in Figure 7 right) increases leaf duration and $\mathrm{C}$ gain by allowing the exploitation of late winter and early spring rainfall.

Within this general framework, the variability of the climatic forcing may cause marked inter-annual variability in $\mathrm{C}$ gains (whiskers in Figure 7 represent the 25th and 75th percentiles). The more consistent seasonality in Mediterranean compared with tropical climates (Figure 2) is mirrored by the lower variability in leaf durations and, as a consequence, in $\mathrm{C}$ gain. Conversely, in tropical SDEs, the inter-annual variability in $\mathrm{C}$ gain within a phenological strategy is comparable with the differences among phenological strategies. It follows that the 'optimal' leaf strategy changes from year to year, explaining the coexistence of the different phenologies in many SDEs. For example, the caatinga (the most common ecosystem in the Santa Terezinha region) comprises species that flush their leaves before the beginning of the wet season, apparently in response to isolated rainfall events (Machado et al., 1997), and scheduled flushers with higher stem water storage (Lima and Rodal, 2010). Moreover, in Northern Australia, a generally evergreen overstory coexists with a drought-deciduous understory (Hutley et al., 2001).

The model results further suggest that access to deeper water stores allows a higher total transpiration and enhance net $\mathrm{C}$ gain, by reducing water lost to deep percolation, and by buffering rainfall intermittency. The buffering effect of deep soils is particularly relevant in Mediterranean drought-deciduous scheduled species, for which a deeper storage allows a better exploitation of winter precipitation, as long as such storage is replenished during the wet season (Viola et al., 2008). While these results are consistent with observations (Schenk and Jackson, 2002) and model predictions (Guswa, 2008; Feng et al., 2012) in both tropical and Mediterranean ecosystems, net $\mathrm{C}$ gain across rooting depths should not be compared here, as root construction and maintenance costs have not been included. In general, while deep roots may provide a $\mathrm{C}$ benefit if the wet season is characterized by deep but intermittent rainfall events, or for Mediterranean species utilizing stored winter rainfall, their cost may not be balanced by enhanced $\mathrm{C}$ uptake in wet climates or when rainfall intermittency in the wet season is low (Guswa, 2008)

Finally, groundwater input to the deeper water store is in most cases beneficial, with the notable exception of opportunistic species (Figure 7 bottom). In fact, the dry season recharge of the deep water store may cause those species to flush their leaves well before the wet season begins, but the little available water is often unable to support plant activity for long periods. The other effect of rainfall-independent groundwater input is buffering against rainfall intermittency, thus generally limiting the interannual variability in net $\mathrm{C}$ gains.

\section{NON-ECOHYDROLOGICAL DRIVERS OF LEAF PHENOLOGY}

The framework discussed here makes it possible to capture the effects of rainfall occurrence on water availability and $\mathrm{C}$ dynamics. Nevertheless, there are other ecological and evolutionary factors that may influence the phenological strategies observed in SDEs, such as herbivore-leaf interactions, fire frequency, nutrient availability, and evolutionary legacies.

In many locations, insect herbivory plays a role in defining the most beneficial leaf phenology (van Schaik et al., 1993; Reich, 1995; Eamus and Prior, 2001; Wilf et al., 2001), with implications for many processes that shape and maintain SDE structure (Coley and Barone, 1996). Plants can invest $\mathrm{C}$ in chemical and physical defences, reducing palatability, at the expense of photosynthetic capacity, and hence C gain and growth rate (Herms and Mattson, 1992; Pringle et al., 2011). This strategy tends to be associated with evergreen species. Conversely, drought-deciduous species maintain high growth rates (which may require high nitrogen content and lead to palatable, tender leaves; Agrawal and Fishbein, 2006) and optimize leaf flushing time to limit leaf predation of young, more palatable leaves. Depending on resource availability, three leaf flushing strategies can be applied. One option is to flush the leaves during the dry season when insects are less prevalent (Aide, 1988; Aide, 1992; Murali and Sukumar, 1993; Sloan et al., 2007); insect damage during the subsequent wet season then occurs on old leaves with decreased photosynthetic capacity. This strategy is feasible only when dry season water storage levels sustain transpiration prior to the wet season. The second strategy is community synchronization of leaf flushing during the wet season, leading to herbivore satiation (Lieberman and Lieberman, 1984; van Schaik et al., 1993). 
A third option is delayed leaf greening, so that leaves become nutritionally appealing only after toughening (Kursar and Coley, 1992).

Fire disturbance may further alter SDE C balance. Fire is a natural event in many Australian, African and Californian SDEs, while it is mainly linked to human presence in South America and in other Mediterranean-type ecosystems (Murphy and Lugo, 1986; Bowman and Prior, 2005), thus resulting in fewer fire-adapted species in the latter SDEs (Lock, 2006). Because fires occur mostly during the dry season, they mainly damage the evergreen species, altering the active leaf lifespan and reducing the benefits of evergreen leaf habit. The frequency of fires may be reduced by the activity of large grazers, which reduce fuel loads (typical of African SDEs).

Nutrient availability may be an additional factor in determining dominant leaf habit. For example, low-fertility Australian soils may favour evergreens (Bowman and Prior, 2005), because their longer lifespan and lower nutrient concentrations enhance nutrient retention in the ecosystem (Aerts, 1995).

Finally, the physiological mechanisms that generate plant responses to phenological cues appear to be highly heritable (Vitasse et al., 2009; Alberto et al., 2011), raising the prospect that observed phenological strategies may not always represent an adaptation to local conditions so much as a legacy of historical climate and species assemblages. For example, although evergreen habit appears to be favourable in Mediterranean climates (Figure 7), evergreen and winter-deciduous species coexist in Mediterranean climates in Europe, the Middle East, and the USA (Blumler, 1991). The origin of this coexistence is hypothesized to lie in Pleistocene climates when cold winters would have eliminated sclerophyllous species and favoured winterdeciduous trees (Wright, 1962; van Zeist, 1967).

\section{SYNTHESIS AND CONCLUSIONS}

Despite differences in temperature regimes, tropical seasonally dry and Mediterranean climates share similarities in their rainfall patterns, in terms of both seasonality and inter-annual variability. Thus, a common framework is appropriate to investigate the ecohydrology of SDEs. To cope with the fluctuations in water availability, plants in SDEs have developed a wide array of adaptation strategies. A synthesis of field observations revealed that leaf phenological strategies, rather than plant ecophysiological traits, provided the greatest source of variation in plant level ecohydrology under a given climate. Leaf phenology therefore plays a crucial role in determining $\mathrm{C}$ and water fluxes in SDEs, as quantitatively explored here by a minimalist ecohydrological model applied to five case studies with contrasting rainfall regimes. Our results suggest that longer and more intense dry seasons favour deciduous plants, while the evergreen leaf habit is beneficial in wetter tropical climates, particularly in the presence of deeper water stores, as well as in Mediterranean ecosystems. Among drought-deciduous species, the inter-annual variability in rainfall is likely to support the coexistence of multiple leaf flushing strategies. Nevertheless, more aggressive strategies (early scheduled flushing or flushing in response to small rainfall events) are generally beneficial when the wet season is consistent and in Mediterranean climates where early spring flushing allows the exploitation of the last part of the wet season and winter water stores. These modelling results are supported by phenological observations across SDEs.

Ongoing and predicted changes in global climate are anticipated to alter seasonal rainfall patterns and thus the functioning of SDEs (Feng et al., 2013). Climatic changes are likely to increase dry season duration and decrease soil moisture in tropical SDEs (Hulme and Viner, 1998; Wetherald and Manabe, 2002; Jung et al., 2010). Changes in the Mediterranean Basin include decreases in mean precipitation and increased variability during the dry season (e.g. Giorgi, 2006; Goubanova and Li, 2007; Alpert et al., 2008; Arnone et al., 2013). If these changes continue, they will stretch the adaptive limits of plants and prompt possible shifts in ecosystem composition and geographical range. On the one hand, decreasing rainfall may shift leaf phenology from evergreen to drought-deciduous species, as rainfall may become insufficient to replenish soil water reserves regularly (Borchert, 1998; Enquist and Enquist, 2011). On the other hand, a less marked seasonality may shift species composition toward a higher fraction of evergreens (Givnish, 2002). Superimposed on these patterns, the projected increases in ambient $\mathrm{CO}_{2}$ concentration may reduce transpiration rates and slow the depletion of soil moisture, further favouring longer leaf lifespans (Reich, 1995) and increasing the total $\mathrm{C}$ gain in deciduous species. However, these beneficial effects of $\mathrm{CO}_{2}$ enrichment might be offset by faster soil water depletion and reduced leaf lifespan caused by the expected increases in temperature and VPD. Shifts in species composition may have significant implications for the long-term water balance of SDEs, with higher abundance of drought-deciduous species resulting in larger fluctuations of soil moisture and an increase in deep percolation and hence groundwater recharge. Also, water availability impacts biogeochemical cycles, so that an increased variability in wet season timing may have deleterious effects on the coordination of nutrient mineralization supply and demand by vegetation (Lodge et al., 1994; Augustine and McNaughton, 2004), and changes in rainfall regimes will likely alter soil C storage (Rohr et al., 2013).

Given the global distribution of SDEs, their ecological complexity and relevance for human activities, and the still limited understanding of ecological fluxes and functioning, 
there is a clear need for additional research, made urgent by the rapid and potentially severe climate change projected for these ecosystems.

\section{ACKNOWLEDGEMENTS}

This research was initiated at the 'Ecohydrology and Sustainability in Seasonally Dry Ecosystems' International Workshop (Duke University, 13-14 June 2011), which was supported by the US National Science Foundation, through grant CBET 10-33467, and by the Pratt School of Engineering, Duke University. We thank Ignacio Rodriguez-Iturbe for the stimulating discussions, and Kathrine Behrman, Virginia L. Jin, and two anonymous reviewers for their comments on earlier versions of the manuscript. The Instituto Fazenda Tamanduá is also acknowledged as a catalyzer of collaboration across institutions and for providing information about the North-Eastern Brazil site. G.V., S.M., X.F., and A.P. gratefully acknowledge the support of the US National Science Foundation (CBET 10-33467, FESD 1338694, DEB-1145875/1145649), the US Department of Agriculture (2011-67003-30222), and the US Department of Energy through the Office of Biological and Environmental Research (BER) Terrestrial Ecosystem Science (TES) Program (DE-SC0006967). G.V. also acknowledges the support of the project 'AgResource - Resource Allocation in Agriculture', from the Faculty of Natural Resources and Agricultural Sciences, Swedish University of Agricultural Sciences (SLU). S.T. acknowledges the US National Science Foundation (EAR-1013339, EAR1331940). A. M. acknowledges the support from the Masdar Institute (One-to-One MIT-MI, \#12WAMA1 and Flagship \#12WAMC1) in the framework of the MIT and Masdar Institute Cooperative Program. P.F. acknowledges support from USDA-NIFA (2010-65615-20632). A.P. also acknowledges the 'Lagrange fellow' project by the CRT Foundation and the Institute for Scientific Interchange.

\section{REFERENCES}

Adams HD, Guardiola-Claramonte M, Barron-Gafford GA, Villegas JC, Breshears DD, Zou CB, Troch PA, Huxman TE. 2009. Temperature sensitivity of drought-induced tree mortality portends increased regional die-off under global-change-type drought. Proceedings of the National Academy of Sciences of the United States of America 106: 7063-7066. DOI: 10.1073/pnas.0901438106.

Aerts R. 1995. The advantages of being evergreen. Trends in Ecology \& Evolution 10: 402-407. DOI: 10.1016/s0169-5347(00)89156-9.

Agrawal AA, Fishbein M. 2006. Plant defense syndromes. Ecology 87: S132-S149.

Aide TM. 1988. Herbivory as a selective agent on the timing of leaf production in a tropical understory community. Nature 336: $574-575$.

Aide TM. 1992. Dry season leaf production - an escape from herbivory. Biotropica 24: 532-537.

Alberto F, Bouffier L, Louvet J, Lamy J, Delzon S, Kremer A. 2011. Adaptive responses for seed and leaf phenology in natural populations of sessile oak along an altitudinal gradient. Journal of Evolutionary Biology 24: 1442-1454.

Allen CD, Macalady AK, Chenchouni $\mathrm{H}$, Bachelet D, McDowell N, Vennetier M, Kitzberger T, Rigling A, Breshears DD, Hogg EH,
Gonzalez P, Fensham R, Zhang Z, Castro J, Demidova N, Lim JH, Allard G, Running SW, Semerci A, Cobb N. 2010. A global overview of drought and heat-induced tree mortality reveals emerging climate change risks for forests. Forest Ecology and Management 259: 660-684. DOI: 10.1016/j.foreco.2009.09.001

Alpert P, Krichak SO, Shafir H, Haim D, Osetinsky I. 2008. Climatic trends to extremes employing regional modeling and statistical interpretation over the E. Mediterranean. Global and Planetary Change 63: 163-170. DOI: 10.1016/j.gloplacha.2008.03.003.

Arnone E, Pumo D, Viola F, Noto LV, La Loggia G. 2013. Rainfall statistics changes in Sicily. Hydrology and Earth System Sciences 17: 2449-2458. DOI: 10.5194/hess-17-2449-2013.

Arora VK, Boer GJ. 2005. A parameterization of leaf phenology for the terrestrial ecosystem component of climate models. Global Change Biology 11: 39-59. DOI: 10.1111/j.1365-2486.2004.00890.x.

Augustine DJ, McNaughton SJ. 2004. Temporal asynchrony in soil nutrient dynamics and plant production in a semiarid ecosystem. Ecosystems 7: 829-840.

Bernacchi CJ, Singsaas EL, Pimentel C, Portis AR, Long SP. 2001. Improved temperature response functions for models of Rubisco-limited photosynthesis. Plant, Cell and Environment 24: 253-259. DOI: 10.1046/j.1365-3040.2001.00668.x.

Blasco F, Whitmore TC, Gers C. 2000. A framework for the worldwide comparison of tropical woody vegetation types. Biological Conservation 95: 175-189. DOI: 10.1016/s0006-3207(00)00032-x.

Blumler M. 1991. Winter-deciduous versus evergreen habit in Mediterranean regions: a model. In Proceedings of the Symposium on Oak Woodlands and Hardwood Rangeland Management. Davis, California.

Borchert R. 1994. Soil and stem water storage determine phenology and distribution of tropical dry forest trees. Ecology 75: 1437-1449. DOI: $10.2307 / 1937467$.

Borchert R. 1998. Responses of tropical trees to rainfall seasonality and its longterm changes. Climatic Change 39: 381-393. DOI: 10.1023/ a: 1005383020063 .

Borchert R, Rivera G. 2001. Photoperiodic control of seasonal development and dormancy in tropical stem-succulent trees. Tree Physiology 21: 213-221.

Bowman D, Prior LD. 2005. Why do evergreen trees dominate the Australian seasonal tropics? Australian Journal of Botany 53: 379-399. DOI: $10.1071 / \mathrm{bt} 05022$.

Brodribb TJ, Holbrook NM. 2005. Leaf physiology does not predict leaf habit; examples from tropical dry forest. Trees - Structure and Function 19: 290-295. DOI: 10.1007/s00468-004-0390-3.

Brodribb TJ, Holbrook NM, Gutierrez MV. 2002. Hydraulic and photosynthetic co-ordination in seasonally dry tropical forest trees. Plant, Cell and Environment 25: 1435-1444. DOI: 10.1046/j.13653040.2002.00919.x.

Brunetti M, Buffoni L, Mangianti F, Maugeri M, Nanni T. 2004. Temperature, precipitation and extreme events during the last century in Italy. Global and Planetary Change 40: 141-149. DOI: 10.1016/s09218181(03)00104-8.

Bucci SJ, Goldstein G, Meinzer FC, Franco AC, Campanello P, Scholz FG. 2005. Mechanisms contributing to seasonal homeostasis of minimum leaf water potential and predawn disequilibrium between soil and plant water potential in neotropical savanna trees. Trees - Structure and Function 19: 296-304. DOI: 10.1007/s00468-004-0391-2.

Bucci SJ, Goldstein G, Meinzer FC, Scholz FG, Franco AC, Bustamante M. 2004. Functional convergence in hydraulic architecture and water relations of tropical savanna trees: from leaf to whole plant. Tree Physiology 24: 891-899.

Buckley TN. 2005. The control of stomata by water balance. New Phytologist 168: 275-291.

Cabral GGAL, Sampaio EVSB, Almeida-Cortez JS. 2013. Estrutura especial e biomassa da parte aérea em diferentes estádios sucessionais de Caatinga, em Santa Terezinha, Paraíba. Revista Brasileira de Geografia Física 6: 566-575.

Canadell J, Jackson RB, Ehleringer JR, Mooney HA, Sala OE, Schulze ED. 1996. Maximum rooting depth of vegetation types at the global scale. Oecologia 108: 583-595. DOI: 10.1007/bf00329030.

Chen JW, Zhang Q, Cao KF. 2009. Inter-species variation of photosynthetic and xylem hydraulic traits in the deciduous and evergreen Euphorbiaceae tree species from a seasonally tropical forest in south-western China. Ecological Research 24: 65-73. 
Choat B, Ball MC, Luly JG, Donnelly CF, Holtum JAM. 2006. Seasonal patterns of leaf gas exchange and water relations in dry rain forest trees of contrasting leaf phenology. Tree Physiology 26: 657-664.

Cianciaruso MV, Silva IA, Manica LT, Souza JP. 2013. Leaf habit does not predict leaf functional traits in cerrado woody species. Basic and Applied Ecology 14: 404-412. DOI: 10.1016/j.baae.2013.05.002.

Cody ML, Mooney HA. 1978. Convergence versus non-convergence in Mediterranean-climate ecosystems. Annual Review of Ecology and Systematics 9: 265-321. DOI: 10.1146/annurev.es.09.110178.001405.

Coley PD, Barone JA. 1996. Herbivory and plant defenses in tropical forests. Annual Review of Ecology and Systematics 27: 305-335. DOI: 10.1146/annurev.ecolsys.27.1.305.

David TS, Henriques MO, Kurz-Besson C, Nunes J, Valente F, Vaz M, Pereira JS, Siegwolf R, Chaves MM, Gazarini LC, David JS. 2007. Water-use strategies in two co-occurring Mediterranean evergreen oaks: surviving the summer drought. Tree Physiology 27: 793-803.

Do FC, Goudiaby VA, Gimenez O, Diagne AL, Diouf M, Rocheteau A, Akpo LE. 2005. Environmental influence on canopy phenology in the dry tropics. Forest Ecology and Management 215: 319-328. DOI: 10.1016/j.foreco.2005.05.022.

Dominguez F, Rivera E, Lettenmaier DP, Castro CL. 2012. Changes in winter precipitation extremes for the western United States under a warmer climate as simulated by regional climate models. Geophysical Research Letters 39. DOI: 10.1029/2011g1050762.

Duff GA, Myers BA, Williams RJ, Eamus D, Ogrady A, Fordyce IR. 1997. Seasonal patterns in soil moisture, vapour pressure deficit, tree canopy cover and pre-dawn water potential in a northern Australian savanna. Australian Journal of Botany 45: 211-224. DOI: 10.1071/bt96018.

Eamus D, Prichard H. 1998. A cost-benefit analysis of leaves of four Australian savanna species. Tree Physiology 18: 537-545.

Eamus D, Prior L. 2001. Ecophysiology of trees of seasonally dry tropics: comparisons among phenologies. Advances in Ecological Research 32: 113-197. DOI: 10.1016/s0065-2504(01)32012-3.

Elliott S, Baker PJ, Borchert R. 2006. Leaf flushing during the dry season: the paradox of Asian monsoon forests. Global Ecology and Biogeography 15: 248-257. DOI: 10.1111/j.1466-822x.2006.00213.x.

Ellis J, Galvin KA. 1994. Climate patterns and land-use practices in the dry zones of Africa. Bioscience 44: 340-349. DOI: 10.2307/1312384.

Enquist BJ, Enquist CAF. 2011. Long-term change within a Neotropical forest: assessing differential functional and floristic responses to disturbance and drought. Global Change Biology 17: 1408-1424. DOI: 10.1111/j.1365-2486.2010.02326.x.

Fallas-Cedeno L, Holbrook NM, Rocha OJ, Vasquez N, Gutierrez-Soto MV. 2010. Phenology, lignotubers, and water relations of Cochlospermum vitifolium, a pioneer tropical dry forest tree in Costa Rica. Biotropica 42: 104-111. DOI: 10.1111/j.1744-7429.2009.00539.x.

Farquhar GD, Sharkey TD. 1982. Stomatal conductance and photosynthesis. Annual Review of Plant Physiology and Plant Molecular Biology 33: 317-345.

Fatichi S, Ivanov VY, Caporali E. 2012. Investigating interannual variability of precipitation at the global scale: is there a connection with seasonality? Journal of Climate 25: 5512-5523. DOI: 10.1175/ jcli-d-11-00356.1.

Feng X, Porporato A, Rodriguez-Iturbe I. 2013. Changes in rainfall seasonality in the tropics. Nature Climate Change 3: 811-815. DOI: 10.1038/nclimate1907.

Feng X, Vico G, Porporato A. 2012. On the effects of seasonality on soil water balance and plant growth. Water Resources Research 48. DOI: 10.1029/2011wr011263.

Fraedrich K, Larnder C. 1993. Scaling regimes of composite rainfall timeseries. Tellus Series a-Dynamic Meteorology and Oceanography 45A: 289-298. DOI: 10.1034/j.1600-0870.1993.t01-3-00004.x.

Franco AC, Bustamante M, Caldas LS, Goldstein G, Meinzer FC, Kozovits AR, Rundel P, Coradin VTR. 2005. Leaf functional traits of Neotropical savanna trees in relation to seasonal water deficit. Trees - Structure and Function 19: 326-335. DOI: 10.1007/s00468-004-0394-z.

Franks PJ, Drake PL, Froend RH. 2007. Anisohydric but isohydrodynamic: seasonally constant plant water potential gradient explained by a stomatal control mechanism incorporating variable plant hydraulic conductance. Plant, Cell and Environment 30: 19-30.

Fu P-L, Jiang Y-J, Wang A-Y, Brodribb TJ, Zhang J-L, Zhu S-D, Cao K-F. 2012. Stem hydraulic traits and leaf water-stress tolerance are co-ordinated with the leaf phenology of angiosperm trees in an Asian tropical dry karst forest. Annals of Botany 110: 189-199. DOI: 10.1093/aob/mcs092.

Galmes J, Medrano H, Flexas J. 2007. Photosynthetic limitations in response to water stress and recovery in Mediterranean plants with different growth forms. New Phytologist 175: 81-93.

Garcia-Ruiz JM, Lopez-Moreno JI, Vicente-Serrano SM, LasantaMartinez T, Begueria S. 2011. Mediterranean water resources in a global change scenario. Earth-Science Reviews 105: 121-139. DOI: 10.1016/j.earscirev.2011.01.006.

Gartner BL, Bullock SH, Mooney HA, Brown VB, Whitbeck JL. 1990. Water transport-properties of vine and tree stems in a tropical deciduous forest. American Journal of Botany 77: 742-749.

Giorgi F. 2006. Climate change hot-spots. Geophysical Research Letters 33: L08707. DOI: 10.1029/2006g1025734.

Givnish TJ. 2002. Adaptive significance of evergreen vs. deciduous leaves: solving the triple paradox. Silva Fennica 36: 703-743.

Goldstein G, Meinzer FC, Bucci SJ, Scholz FG, Franco AC, Hoffmann WA. 2008. Water economy of Neotropical savanna trees: six paradigms revisited. Tree Physiology 28: 395-404.

Goubanova K, Li L. 2007. Extremes in temperature and precipitation around the Mediterranean basin in an ensemble of future climate scenario simulations. Global and Planetary Change 57: 27-42. DOI: 10.1016/j.gloplacha.2006.11.012.

Green SR, Clothier BE, McLeod DJ. 1997. The response of sap flow in apple roots to localised irrigation. Agricultural Water Management 33: 63-78. DOI: 10.1016/s0378-3774(96)01277-2.

Guswa AJ. 2008. The influence of climate on root depth: a carbon costbenefit analysis. Water Resources Research 44. DOI: 10.1029/ 2007wr006384.

Guswa AJ. 2012. Canopy vs. roots: production and destruction of variability in soil moisture and hydrologic fluxes. Vadose Zone Journal 11. DOI: $10.2136 /$ vzj2011.0159.

Hari P, Makela A, Korpilahti E, Holmberg M. 1986. Optimal control of gas exchange. Tree Physiology 2: 169-175.

Hasselquist NJ, Allen MF, Santiago LS. 2010. Water relations of evergreen and drought-deciduous trees along a seasonally dry tropical forest chronosequence. Oecologia 164: 881-890. DOI: 10.1007/ s00442-010-1725-y.

Herms DA, Mattson WJ. 1992. The dilemma of plants - to grow or defend. Quarterly Review of Biology 67: 283-335.

Hoffman AJ, Walker MJ. 1980. Growth habits and phenology of droughtdeciduous species in an altitudinal gradient. Canadian Journal of Botany 58: 1789-1796.

Hulme M, Viner D. 1998. A climate change scenario for the tropics. Climatic Change 39: 145-176. DOI: 10.1023/a:1005376007729.

Hutley LB, O'Grady AP, Eamus D. 2001. Monsoonal influences on evapotranspiration of savanna vegetation of northern Australia. Oecologia 126: 434-443. DOI: 10.1007/s004420000539.

Ishida A, Harayama H, Yazaki K, Ladpala P, Sasrisang A, Kaewpakasit K, Panuthai S, Staporn D, Maeda T, Gamo M, Diloksumpun S, Puangchit L, Ishizuka M. 2010. Seasonal variations of gas exchange and water relations in deciduous and evergreen trees in monsoonal dry forests of Thailand. Tree Physiology 30: 935-945. DOI: 10.1093/ treephys/tpq025.

Jackson PC, Cavelier J, Goldstein G, Meinzer FC, Holbrook NM. 1995. Partitioning of water-resources among plants of a lowland tropical forest. Oecologia 101: 197-203. DOI: 10.1007/bf00317284.

Jackson PC, Meinzer FC, Bustamante M, Goldstein G, Franco A, Rundel PW, Caldas L, Igler E, Causin F. 1999. Partitioning of soil water among tree species in a Brazilian Cerrado ecosystem. Tree Physiology 19: 717-724.

Joffre R, Rambal S, Damesin C. 1999. Functional attributes in Mediterraneantype ecosystems. In Handbook of Functional Plant Ecology, Pugnaire FI, Valladares F (eds). Marcel Dekker: New York; 347-380.

Jolly WM, Running SW. 2004. Effects of precipitation and soil water potential on drought deciduous phenology in the Kalahari. Global Change Biology 10: 303-308. DOI: 10.1046/j.1529-8817.2003.00701.x.

Jung M, Reichstein M, Ciais P, Seneviratne SI, Sheffield J, Goulden ML, Bonan G, Cescatti A, Chen J, de Jeu R, Dolman AJ, Eugster W, Gerten D, Gianelle D, Gobron N, Heinke J, Kimball J, Law BE, Montagnani L, Mu Q, Mueller B, Oleson K, Papale D, Richardson AD, Roupsard O, Running S, Tomelleri E, Viovy N, Weber U, Williams C, Wood E, Zaehle S, Zhang K. 2010. Recent decline in the global land evapotranspiration 
trend due to limited moisture supply. Nature 467: 951-954. DOI: 10.1038/nature09396.

Kane RP. 1997. On the relationship of ENSO with rainfall over different parts of Australia. Australian Meteorological Magazine 46: 39-49.

Kang SZ, Hu X, Jerie P, Zhang JH. 2003. The effects of partial rootzone drying on root, trunk sap flow and water balance in an irrigated pear (Pyrus communis L.) orchard. Journal of Hydrology 280: 192-206. DOI: $10.1016 / \mathrm{s} 0022-1694(03) 00226-$.

Kayano MT, Andreoli RV. 2006. Relationships between rainfall anomalies over northeastern Brazil and the El Nino-Southern Oscillation. Journal of Geophysical Research-Atmospheres 111. DOI: 10.1029/2005jd006142

Klausmeyer KR, Shaw MR. 2009. Climate change, habitat loss, protected areas and the climate adaptation potential of species in Mediterranean ecosystem worldwide. Plos One 4: e6392. DOI: 10.1371/journal.pone.0006392.

Knippertz P, Christoph M, Speth P. 2003. Long-term precipitation variability in Morocco and the link to the large-scale circulation in recent and future climates. Meteorology and Atmospheric Physics 83: 67-88. DOI: 10.1007/s00703-002-561-y.

Kostopoulou E, Jones PD. 2005. Assessment of climate extremes in the Eastern Mediterranean. Meteorology and Atmospheric Physics 89: 69-85. DOI: 10.1007/s00703-005-0122-2.

Kottek M, Grieser J, Beck C, Rudolf B, Rubel F. 2006. World map of the Koppen-Geiger climate classification updated. Meteorologische Zeitschrift 15: 259-263.

Kursar TA, Coley PD. 1992. Delayed greening in tropical leaves - an antiherbivore defense. Biotropica 24: 256-262.

Kurz-Besson C, Otieno D, do Vale RL, Siegwolf R, Schmidt M, Herd A, Nogueira C, David TS, David JS, Tenhunen J, Pereira JS, Chaves M. 2006. Hydraulic lift in cork oak trees in a savannah-type Mediterranean ecosystem and its contribution to the local water balance. Plant and Soil 282: 361-378. DOI: $10.1007 / \mathrm{s} 11104-006-0005-4$.

Kushwaha CP, Singh KP. 2005. Diversity of leaf phenology in a tropical deciduous forest in India. Journal of Tropical Ecology 21: 47-56. DOI $10.1017 / \mathrm{s} 0266467404002032$.

Laio F, Porporato A, Ridolfi L, Rodriguez-Iturbe I. 2001. Plants in watercontrolled ecosystems: active role in hydrologic processes and response to water stress - II. Probabilistic soil moisture dynamics. Advances in Water Resources 24: 707-723. DOI: 10.1016/s0309-1708(01)00005-7.

Lawlor DW, Tezara W. 2009. Causes of decreased photosynthetic rate and metabolic capacity in water-deficient leaf cells: a critical evaluation of mechanisms and integration of processes. Annals of Botany 103: 561-579.

Legates DR, Willmott CJ. 1989. Average monthly surface air temperature and precipitation. Digital raster data on a .5 degree geographic (lat/long) $361 \times 721$ grid (centroid-registered on .5 degree meridians). Research NCfA ed.: Boulder, CO

Lehmann CER, Ratnam J, Hutley LB. 2009. Which of these continents is not like the other? Comparisons of tropical savanna systems: key questions and challenges. New Phytologist 181: 508-511. DOI: 10.1111/j.1469-8137.2009.02734.x.

Lieberman D, Lieberman M. 1984. The causes and consequences of synchronous flushing in a dry tropical forest. Biotropica 16: 193-201.

Lima ALA, Rodal MJN. 2010. Phenology and wood density of plants growing in the semi-arid region of northeastern Brazil. Journal of Arid Environments 74: 1363-1373. DOI: 10.1016/j.jaridenv.2010.05.009.

Lock JM. 2006. The seasonally dry vegetation of Africa: parallels and comparisons with the Neotropics. In Neotropical Svannas and Seasonally Dry Forests: Plant Diversity, Biogeography, and Conservation, Pennington RT, Lewis GP, Ratter JA (eds). CRC Press: Boca raton, FL; 449-467.

Lodge DJ, McDowell WH, McSwiney CP. 1994. The importance of nutrient pulses in tropical forests. Trends in Ecology \& Evolution 9: 384-387.

Maass JM, Balvanera P, Castillo A, Daily GC, Mooney HA, Ehrlich P, Quesada M, Miranda A, Jaramillo VJ, Garcia-Oliva F, Martinez-Yrizar A, Cotler H, Lopez-Blanco J, Perez-Jimenez A, Burquez A, Tinoco C, Ceballos G, Barraza L, Ayala R, Sarukhan J. 2005. Ecosystem services of tropical dry forests: insights from long-term ecological and social research on the Pacific Coast of Mexico. Ecology and Society 10.

Machado ICS, Barros LM, Sampaio E. 1997. Phenology of caatinga species at Serra Talhada, PE, Northeastern Brazil. Biotropica 29: 57-68.

Manzoni S, Vico G, Katul G, Fay PA, Polley W, Palmroth S, Porporato A. 2011. Optimizing stomatal conductance for maximum carbon gain under water stress: a meta-analysis across plant functional types and climates. Functional Ecology 25: 456-467.

Manzoni S, Vico G, Katul G, Palmroth S, Porporato A. 2014. Optimal plant water-use strategies under stochastic rainfall. Water Resources Research 50. DOI: 10.1002/2014WR015375.

Manzoni S, Vico G, Katul GG, Porporato A. 2013. Biological constraints on water transport in the soil-plant-atmosphere system. Advances in Water Resources 51: 292-304. DOI: 10.1016/j.advwatres.2012.1003.1016.

Markesteijn L, Poorter L, Paz H, Sack L, Bongers F. 2011. Ecological differentiation in xylem cavitation resistance is associated with stem and leaf structural traits. Plant, Cell and Environment 34: 137-148. DOI: 10.1111/j.1365-3040.2010.02231.x.

Mason SJ, Goddard L. 2001. Probabilistic precipitation anomalies associated with ENSO. Bulletin of the American Meteorological Society 82: 619-638. DOI: 10.1175/1520-0477(2001)082<0619:ppaawe >2.3.co;2.

McDowell NG, Beerling DJ, Breshears DD, Fisher RA, Raffa KF, Stitt M. 2011. The interdependence of mechanisms underlying climate-driven vegetation mortality. Trends in Ecology \& Evolution 26: 523-532. DOI: 10.1016/j.tree.2011.06.003.

Mediavilla S, Garcia-Ciudad A, Garcia-Criado B, Escudero A. 2008. Testing the correlations between leaf life span and leaf structural reinforcement in 13 species of European Mediterranean woody plants. Functional Ecology 22: 787-793. DOI: 10.1111/j.13652435.2008.01453.x.

Meinzer FC, Campanello PI, Domec JC, Gatti MG, Goldstein G, Villalobos-Vega R, Woodruff DR. 2008. Constraints on physiological function associated with branch architecture and wood density in tropical forest trees. Tree Physiology 28: 1609-1617.

Meinzer FC, Goldstein G, Franco AC, Bustamante M, Igler E, Jackson P, Caldas L, Rundel PW. 1999. Atmospheric and hydraulic limitations on transpiration in Brazilian cerrado woody species. Functional Ecology 13: 273-282. DOI: 10.1046/j.1365-2435.1999.00313.x.

Menaut J-C, Lepage M, Abbadie L. 1995. Savannas, woodland and dry forests in Africa. In Seasonally Dry Tropical Forests, Bullock SH, Mooney HA, Medina E (eds). Cambridge University Press: Cambridge; 64-92.

Miles L, Newton AC, DeFries RS, Ravilious C, May I, Blyth S, Kapos V, Gordon JE. 2006. A global overview of the conservation status of tropical dry forests. Journal of Biogeography 33: 491-505. DOI: 10.1111/j.1365-2699.2005.01424.x.

Miller GR, Chen XY, Rubin Y, Ma SY, Baldocchi DD. 2010. Groundwater uptake by woody vegetation in a semiarid oak savanna. Water Resources Research 46. DOI: 10.1029/2009wr008902.

Milly PCD. 2001. A minimalist probabilistic description of root zone soil water. Water Resources Research 37: 457-463. DOI: 10.1029/ 2000 wr900337.

Miranda JD, Padilla FM, Martinez-Vilalta J, Pugnaire FI. 2010. Woody species of a semi-arid community are only moderately resistant to cavitation. Functional Plant Biology 37: 828-839. DOI: 10.1071/fp09296.

Molini A, Katul GG, Porporato A. 2010. Scale-wise evolution of rainfall probability density functions fingerprints the rainfall generation mechanism. Geophysical Research Letters 37: Artn L07403. DOI: $10.1029 / 2010 \mathrm{gl} 1042634$

Murali KS, Sukumar R. 1993. Leaf flushing phenology and herbivory in a tropical dry deciduous forest, Southern India. Oecologia 94: 114-119.

Murphy PG, Lugo AE. 1986. Ecology of tropical dry forest. Annual Review of Ecology and Systematics 17: 67-88. DOI: 10.1146/annurev. ecolsys.17.1.67.

Myerscough MR, Murray JD. 1992. Analysis of propagating pattern in a chemotaxis system. Bulletin of Mathematical Biology 54: 77-94.

Nepstad DC, Decarvalho CR, Davidson EA, Jipp PH, Lefebvre PA, Negreiros GH, Dasilva ED, Stone TA, Trumbore SE, Vieira S. 1994. The role of deep roots in the hydrological and carbon cycles of Amazonian forests and pastures. Nature 372: 666-669. DOI: 10.1038/ $372666 \mathrm{a} 0$.

Neumann RB, Cardon ZG. 2012. The magnitude of hydraulic redistribution by plant roots: a review and synthesis of empirical and modeling studies. New Phytologist 194: 337-352. DOI: $10.1111 / \mathrm{j} .1469-$ 8137.2012.04088.x.

van Ommen Kloeke AEE, Douma JC, Ordonez JC, Reich PB, van Bodegom PM. 2012. Global quantification of contrasting leaf life span strategies for deciduous and evergreen species in response to 
environmental conditions. Global Ecology and Biogeography 21: 224235. DOI: 10.1111/j.1466-8238.2011.00667.x.

Oren R, Sperry JS, Katul GG, Pataki DE, Ewers BE, Phillips N, Schafer KVR. 1999. Survey and synthesis of intra- and interspecific variation in stomatal sensitivity to vapour pressure deficit. Plant, Cell and Environment 22: 1515-1526. DOI: 10.1046/j.1365-3040.1999.00513.x.

Peguero-Pina JJ, Sancho-Knapik D, Morales F, Flexas J, Gil-Pelegrin E. 2009. Differential photosynthetic performance and photoprotection mechanisms of three Mediterranean evergreen oaks under severe drought stress. Functional Plant Biology 36: 453-462.

Penuelas J, Filella I, Comas P. 2002. Changed plant and animal life cycles from 1952 to 2000 in the Mediterranean region. Global Change Biology 8: 531-544. DOI: 10.1046/j.1365-2486.2002.00489.x.

Penuelas J, Filella I, Zhang XY, Llorens L, Ogaya R, Lloret F, Comas P, Estiarte M, Terradas J. 2004. Complex spatiotemporal phenological shifts as a response to rainfall changes. New Phytologist 161: 837-846. DOI: $10.1111 /$ j.1469-8137.2004.01003.x.

Porporato A, Daly E, Rodriguez-Iturbe I. 2004. Soil water balance and ecosystem response to climate change. American Naturalist 164: 625-632. DOI: $10.1086 / 424970$.

Prasad SN, Hedge M. 1986. Phenology and seasonality in the tropical deciduous forest of Bandipur, South India. Proceedings of the Indian Academy of Sciences Plant Science(Plant Science) 96: 121-133.

Prieto I, Kikvidze Z, Pugnaire FI. 2010. Hydraulic lift: soil processes and transpiration in the Mediterranean leguminous shrub Retama sphaerocarpa (L.) Boiss. Plant and Soil 329: 447-456. DOI: 10.1007/ s11104-009-0170-3.

Pringle EG, Adams RI, Broadbent E, Busby PE, Donatti CI, Kurten EL, Renton K, Dirzo R. 2011. Distinct leaf-trait syndromes of evergreen and deciduous trees in a seasonally dry tropical forest. Biotropica 43: 299-308. DOI: $10.1111 /$ j.1744-7429.2010.00697.x.

Quero JL, Sterck FJ, Martinez-Vilalta J, Villar R. 2011. Water-use strategies of six co-existing Mediterranean woody species during a summer drought. Oecologia 166: 45-57. DOI: 10.1007/s00442-011-1922-3.

Rao VB, Delima MC, Franchito SH. 1993. Seasonal and interannual variations of rainfall over Eastern Northeast Brazil. Journal of Climate 6: $1754-1763$

Reich PB. 1995. Phenology of tropical forests - patterns, causes, and consequences Canadian Journal of Botany-Revue Canadienne De Botanique 73: 164-174.

Reich PB, Borchert R. 1984. Water stress and tree phenology in a tropical dry forest in the lowlands of Costa Rica. Journal of Ecology 72: 61-74.

Rivera G, Elliott S, Caldas LS, Nicolossi G, Coradin VTR, Borchert R. 2002. Increasing day-length induces spring flushing of tropical dry forest trees in the absence of rain. Trees - Structure and Function 16: 445-456. DOI: 10.1007/s00468-002-0185-3.

Rodrigo FS, Trigo RM. 2007. Trends in daily rainfall in the Iberian Peninsula from 1951 to 2002. International Journal of Climatology 27: 513-529. DOI: 10.1002/joc. 1409.

Rodrigues RR, Haarsma RJ, Campos EJD, Ambrizzi T. 2011. The impacts of inter-El Nino variability on the tropical Atlantic and northeast Brazil climate. Journal of Climate 24: 3402-3422. DOI: 10.1175/ 2011 jcli3983.1.

Rohr T, Manzoni S, Feng X, Menezes RSC, Porporato A. 2013. Effect of rainfall seasonality on carbon storage in tropical dry ecosystems. Journal of Geophysical Research-Biogeosciences 118: 1156-1167. DOI: 10.1002/jgrg.20091.

Sampaio EVSB. 1995. Overview of Brazilian caatinga. In Seasonally Dry Tropical Forests, Bullock SH, Mooney HA, Medina E (eds). Cambridge University Press: Cambridge; 35-63.

Santiago LS, Goldstein G, Meinzer FC, Fisher JB, Machado K, Woodruff D, Jones T. 2004. Leaf photosynthetic traits scale with hydraulic conductivity and wood density in Panamanian forest canopy trees. Oecologia 140: 543-550. DOI: 10.1007/s00442-004-1624-1.

van Schaik CP, Terborgh JW, Wright SJ. 1993. The phenology of tropical forests - adaptive significance and consequences for primary consumers. Annual Review of Ecology and Systematics 24: 353-377.

Schenk HJ, Jackson RB. 2002. The global biogeography of roots. Ecological Monographs 72: 311-328. DOI: 10.2307/3100092.

Scholz FG, Bucci SJ, Goldstein G, Moreira MZ, Meinzer FC, Domec JC, Villalobos-Vega R, Franco AC, Miralles-Wilhelm F. 2008. Biophysical and life-history determinants of hydraulic lift in Neotropical savanna trees. Functional Ecology 22: 773-786. DOI: 10.1111/j.13652435.2008.01452.x.

Singh KP, Kushwaha CP. 2005a. Emerging paradigms of tree phenology in dry tropics. Current Science 89: 964-975.

Singh KP, Kushwaha CP. 2005b. Paradox of leaf phenology: Shorea robusta is a semi-evergreen species in tropical dry deciduous forests in India. Current Science 88: 1820-1824.

Sloan SA, Zimmerman JK, Sabat AM. 2007. Phenology of Plumeria alba and its herbivores in a tropical dry forest. Biotropica 39: 195-201.

Sobrado MA. 1986. Aspects of tissue water relations and seasonal changes of leaf water potential components of evergreen and deciduous species coexisting in tropical dry forests. Oecologia 68: 413-416. DOI: $10.1007 / \mathrm{bf} 01036748$.

Sobrado MA. 1993a. Trade-off between water transport efficiency and leaf life-span in a tropical dry forest. Oecologia 96: 19-23. DOI: 10.1007/ bf00318025.

Sobrado MA. 1993b. Trade-off between water transport efficiency and leaf life-span in a tropical dry forest. Oecologia 96: 19-23. DOI: 10.1007/bf00318025.

Solomon S, Qin D, Manning M, Chen Z, Marquis M, Averyt K, Tignor MMB, Miller HL. 2007. Contribution of Working Group I to the Fourth Assessment Report of the Intergovernmental Panel on Climate Change, 2007. Cambridge University Press: Cambridge, UK and New York, NY, USA.

Torrence C, Compo GP. 1998. A practical guide to wavelet analysis. Bulletin of the American Meteorological Society 79: 61-78.

Tyree MT, Ewers FW. 1991. The hydraulic architecture of trees and other woody-plants. New Phytologist 119: 345-360.

Underwood EC, Viers JH, Klausmeyer KR, Cox RL, Shaw MR. 2009. Threats and biodiversity in the Mediterranean biome. Diversity and Distributions 15: 188-197. DOI: 10.1111/j.1472-4642.2008.00518.x.

Valdez-Hernandez M, Andrade JL, Jackson PC, Rebolledo-Vieyra M. 2010. Phenology of five tree species of a tropical dry forest in Yucatan, Mexico: effects of environmental and physiological factors. Plant and Soil 329: 155-171. DOI: 10.1007/s11104-009-0142-7.

Vico G, Porporato A. 2008. Modelling $\mathrm{C}_{3}$ and $\mathrm{C}_{4}$ photosynthesis under water-stressed conditions. Plant and Soil 313: 187-203.

Vico G, Porporato A. 2010. Traditional and microirrigation with stochastic soil moisture. Water Resources Research 46: W03509. DOI: 10.1029/ 2009wr008130.

Viola F, Daly E, Vico G, Cannarozzo M, Porporato A. 2008. Transient soil-moisture dynamics and climate change in Mediterranean ecosystems. Water Resources Research 44. DOI: 10.1029/2007wr006371.

Vitasse Y, Delzon S, Dufrêne E, Pontailler J-Y, Louvet J-M, Kremer A, Michalet R. 2009. Leaf phenology sensitivity to temperature in European trees: do within-species populations exhibit similar responses? Agricultural and Forest Meteorology 149: 735-744.

Wetherald RT, Manabe S. 2002. Simulation of hydrologic changes associated with global warming. Journal of Geophysical ResearchAtmospheres 107. DOI: $10.1029 / 2001 \mathrm{jd} 001195$.

Wilf P, Labandeira CC, Johnson KR, Coley PD, Cutter AD. 2001. Insect herbivory, plant defense, and early Cenozoic climate change. Proceedings of the National Academy of Sciences of the United States of America 98: 6221-6226.

Williams RJ, Myers BA, Muller WJ, Duff GA, Eamus D. 1997. Leaf phenology of woody species in a North Australian tropical savanna. Ecology 78: 2542-2558. DOI: 10.1890/0012-9658(1997)078[2542: lpowsi]2.0.co;2.

Wright HE. 1962. Pleistocene glaciation in Kurdistan. Eiszeitalter und Gegenwart 12: 131-164.

Wright IJ, Reich PB, Westoby M, Ackerly DD, Baruch Z, Bongers F, Cavender-Bares J, Chapin T, Cornelissen JHC, Diemer M, Flexas J, Garnier E, Groom PK, Gulias J, Hikosaka K, Lamont BB, Lee T, Lee W, Lusk C, Midgley JJ, Navas ML, Niinemets U, Oleksyn J, Osada N, Poorter H, Poot P, Prior L, Pyankov VI, Roumet C, Thomas SC, Tjoelker MG, Veneklaas EJ, Villar R. 2004. The worldwide leaf economics spectrum. Nature 428: 821-827. DOI: 10.1038/nature02403.

Wright SJ, Cornejo FH. 1990. Seasonal drought and leaf fall in a tropical forest. Ecology 7: 1165-1175.

Xu LK, Baldocchi DD. 2003. Seasonal trends in photosynthetic parameters and stomatal conductance of blue oak (Quercus douglasii) under prolonged summer drought and high temperature. Tree Physiology 23: 865-877. 


\section{G. VICO et al.}

Yoshifuji N, Komatsu H, Kumagai T, Tanaka N, Tantasirin C, Suzuki M. 2011. Interannual variation in transpiration onset and its predictive indicator for a tropical deciduous forest in northern Thailand based on 8-year sap-flow records. Ecohydrology 4: 225-235. DOI: 10.1002/ eco.219.

Yu KL, D'Odorico P. 2014. Climate, vegetation, and soil controls on hydraulic redistribution in shallow tree roots. Advances in Water Resources 66: 70-80. DOI: 10.1016/j.advwatres.2014.02.003. van Zeist W. 1967. Late Quaternary vegetation history of western Iran. Review of Palaeobotany and Palynology 2: 301-311.

\section{SUPPORTING INFORMATION}

Additional supporting information may be found in the online version of this article at the publisher's web site. 